\title{
Change of Tensile Properties with Aging Time and Temperature in Al-Si-Cu-Mg 354 Cast Alloys with/without Minor Addition of $\mathrm{Ni}$ and/or $\mathrm{Zr}$
}

\author{
J. Hernandez-Sandoval, ${ }^{1}$ M. H. Abdelaziz $\mathbb{D}^{\circ},{ }^{2}$ E. A. Elsharkawi, ${ }^{3}$ A. M. Samuel $\left(\mathbb{D},{ }^{4}\right.$ \\ and F. H. Samuel $\mathbb{D D}^{4}$ \\ ${ }^{1}$ Facultad de Ingeniería Mecánica y Eléctrica, Universidad Autónoma de Nuevo Leon, San Nicolás de los Garza, Mexico \\ ${ }^{2}$ Département PEC, Université Française d'Égypte, Ville Shorouk, Le Caire, Egypt \\ ${ }^{3}$ Division of Engineering, Saint Mary's University, Halifax, Canada \\ ${ }^{4}$ Département des Sciences Appliquées, Université du Québec à Chicoutimi, Saguenay, Canada
}

Correspondence should be addressed to F. H. Samuel; fhsamuel@uqac.ca

Received 1 February 2021; Revised 27 February 2021; Accepted 15 March 2021; Published 7 April 2021

Academic Editor: Jörg M. K. Wiezorek

Copyright $\odot 2021 \mathrm{~J}$. Hernandez-Sandoval et al. This is an open access article distributed under the Creative Commons Attribution License, which permits unrestricted use, distribution, and reproduction in any medium, provided the original work is properly cited.

\begin{abstract}
The principal aim of the present research work was to investigate the effects of minor additions of nickel and zirconium on the strength of cast aluminum alloy 354 at room temperature $\left(25^{\circ} \mathrm{C}\right)$. A decrease in tensile properties of $\sim 10 \%$ with the addition of $0.4 \mathrm{wt}$.\% nickel is attributed to a nickel-copper reaction which interferes with the formation of $\mathrm{Al}_{2} \mathrm{Cu}$ precipitates. The plateletlike phases $(\mathrm{Al}, \mathrm{Si})_{3}(\mathrm{Zr}, \mathrm{Ni}, \mathrm{Fe})$ and $(\mathrm{Al}, \mathrm{Si})_{3}(\mathrm{Zr}, \mathrm{Ti})$ are the main features observed in the microstructures of the tensile samples of alloys with $\mathrm{Zr}$ additions. The reduction in mechanical properties is due to the increase in the percentage of intermetallic phases formed during solidification; such particles would act as stress concentrators, decreasing the alloy ductility. The main effect of $\mathrm{Zr}$ addition lies in a significant reduction in the alloy grain size $\sim 40 \%$, rather than an increase in the mechanical properties. Quality index charts could be used in assessing the effects of the $\mathrm{Ni}$ and $\mathrm{Zr}$ additions to the base alloy, as well as evaluating the heat treatment relationships to the alloy tensile properties, in particular when the system shows multiple precipitation reactions. Due to the high liquidus temperature of the Al-Zr binary phase diagram, addition of $\mathrm{Zr}$ beyond $0.2 \%$ is not recommended to avoid undissolved $\mathrm{Zr}$.
\end{abstract}

\section{Introduction}

The aging treatment of an aluminum alloy containing copper as the alloying element results in the formation of various forms of $\mathrm{Al}-\mathrm{Cu}$-containing precipitates. The precipitation sequence of an Al-Cu alloy during the aging process has been proposed as follows [1-3]:

$$
\alpha(\mathrm{SSS}) \longrightarrow \mathrm{GP} \text { zones } \longrightarrow \theta^{\prime \prime} \longrightarrow \theta^{\prime} \longrightarrow \theta .
$$

The coherent and semicoherent phases, $\theta^{\prime \prime}$ and $\theta^{\prime}$, respectively, contribute to increasing the strength of the alloys. On the other hand, the incoherent equilibrium precipitate $\theta \quad\left(\mathrm{Al}_{2} \mathrm{Cu}\right)$ results in diminishing the hardening level of the alloys because of the loss of coherency between the stable phases and the metal matrix. With regard to an aluminum alloy containing $\mathrm{Cu}$ and $\mathrm{Mg}$ as the hardening elements, the aging treatment results in the formation of a range of precipitates. The generally accepted sequence of precipitation in $\mathrm{Al}-\mathrm{Cu}-\mathrm{Mg}$ alloys is $[4,5] \theta-\mathrm{Al}_{2} \mathrm{Cu}$ precipitate and its precursors, along with other hardening phases/precipitates such as the $\mathrm{S}-\mathrm{Al}_{2} \mathrm{CuMg}$ phase and its precursors, which are observed to form during the aging treatment of an aluminum alloy containing $\mathrm{Cu}$ and $\mathrm{Mg}$. The formation of the $\mathrm{S}$ phases during aging treatment occurs via the following precipitation sequence $[6-10]$ : 


$$
\alpha(\mathrm{SSS}) \longrightarrow \text { GPB zones } \longrightarrow S^{\prime \prime} \longrightarrow S^{\prime} \longrightarrow S
$$

starting with the decomposition of the supersaturated solid solution (SSS), followed firstly by the formation of GPB (Guinier-Preston-Bagaryatsky) zones and then by the precipitation of the coherent $S^{\prime \prime}$ and the semicoherent $S^{\prime}$ and finally the incoherent equilibrium $S\left(\mathrm{Al}_{2} \mathrm{CuMg}\right)$ phase. The coherent $S^{\prime \prime}$ and the semicoherent $S^{\prime}$ precipitates are the main source of hardening in aluminum alloys containing $\mathrm{Cu}$ and $\mathrm{Mg}$, and they are also responsible for increasing the strengthening level of this type of alloy, whereas over aging conditions result in the precipitation of the incoherent equilibrium $S$ phase. Moreover, there is another phase containing Si which may form in the Al-Cu-Mg-Si system, called the $Q$ phase or quaternary $\mathrm{Al}_{4} \mathrm{Mg}_{8} \mathrm{Cu}_{2} \mathrm{Si}_{6}$ phase which can form upon solidification or during aging [11-14]. This $Q$ phase can also coexist with $\mathrm{Al}_{2} \mathrm{Cu}, \mathrm{Mg}_{2} \mathrm{Si}$, and $\mathrm{Si}$ depending on the ratio between $\mathrm{Cu}, \mathrm{Mg}$, and $\mathrm{Si}$. One of the suggested mechanisms for the formation of the $Q$ phase is that the $\mathrm{Cu}$ atoms dissolve in the $\beta$ " which then evolves either to $\beta$ $\left(\mathrm{Mg}_{2} \mathrm{Si}\right)$ or to the $Q$ phase based on the chemical composition of the alloy and precipitation status $[15,16]$.

The $\mathrm{Mg} / \mathrm{Si}$ ratio, the $\mathrm{Cu} / \mathrm{Mg}$ ratio, as well as the $\mathrm{Cu}$ and $\mathrm{Si}$ contents are all principal controlling factors which determine the main precipitation-hardening phases in $\mathrm{Al}-\mathrm{Cu}-$ $\mathrm{Mg}$-Si alloys. The strengthening mechanism results from an age-hardening treatment which depends on the interaction between the moving dislocations and the precipitated phases [17-19]. The addition of copper to Al-Si alloys leads to the formation of the copper intermetallic phase, which increases the alloy strength both at room and at high temperatures. This intermetallic phase is present in three forms: (i) eutectic-like $\mathrm{Al}-\mathrm{Al}_{2} \mathrm{Cu}$, (ii) block-like $\mathrm{Al}_{2} \mathrm{Cu}$, and (iii) Q$\mathrm{Al}_{4} \mathrm{Mg}_{8} \mathrm{Cu}_{2} \mathrm{Si}_{6}$ phases. Silicon alone contributes very little to the strength of aluminum casting alloys yet provides a very effective level of strengthening when combined with magnesium to form $\mathrm{Mg}_{2} \mathrm{Si}$. The $\mathrm{Mg}_{2} \mathrm{Si}$ phase is soluble in the alloy to a limit of $\sim 0.7 \% \mathrm{Mg}$ and provides the precipitation strengthening basis for heat-treatable alloys.

According to Refs. [20, 21], it would be important to produce a microstructure containing coarsening-resistant dispersoids in order to enhance the alloy mechanical properties at high temperatures in an aluminum alloy. Zirconium has the smallest diffusion flux in aluminum of all the transition metals [22], leading to the formation of the $\mathrm{Al}_{3} \mathrm{Zr}$ phase, which precipitates out during the initial solution heat treatment in the form of metastable $\mathrm{Ll}_{2} \mathrm{Al}_{3} \mathrm{Zr}$ particles. These particles are resistant to dissolution and coarsening; they can also control the evolution of the grain and subgrain structure, thereby making it possible to increase strength and ductility in the precipitation-hardened T6 condition [23] or during subsequent processing operations, such as the hot rolling of wrought alloys.

The capacity of nickel for improving the strength of wrought aluminum alloys at high temperatures has already been established; nickel is thus used in combination with copper to enhance high temperature properties [24]. The solid solubility of nickel in aluminum cannot exceed $0.04 \%$. If this amount is exceeded, then it is present as an insoluble intermetallic, usually in combination with iron. Nickel content of up to $2 \%$ increases the strength of high-purity aluminum but reduces its ductility. Binary aluminum-nickel alloys are no longer in use, but nickel is added to aluminumcopper and aluminum-silicon alloys to improve both hardness and strength parameters at elevated temperatures as well as to reduce the coefficient of thermal expansion [25].

Intermetallic phases in an $\mathrm{Al}-14 \mathrm{Si}-3 \mathrm{Cu}-4.5 \mathrm{Ni}$ casting alloy with trace additions of $\mathrm{Zr}$ were investigated by Jo et al. [26] who reported on a new Zr-rich intermetallic $(\mathrm{Al}, \mathrm{Si})_{3}(\mathrm{Zr}, \mathrm{Ni}, \mathrm{Fe})$ phase with a tetragonal structure with $a=3.275 \AA$ and $c=15.475 \AA$. Strengthening mechanisms at ambient and elevated temperatures were studied by Michi et al. [27] in a cast $\mathrm{Al}-0.11 \mathrm{Zr}-0.02 \mathrm{Si}-0.005 \mathrm{Er}$ (at.\%) alloy containing 2.86 at.\% $\mathrm{Ni}$. The strengthening process is composed of (i) incoherent $\mathrm{Al}_{3} \mathrm{Ni}$ microfibers formed during eutectic solidification and (ii) coherent, equiaxed $\mathrm{Al}_{3} \mathrm{Zr}\left(\mathrm{Ll}_{2^{-}}\right.$ structure) nanoprecipitates created on subsequent aging. Tunçay et al. [28] investigated the effects of $\mathrm{Cr}$ and $\mathrm{Zr}$ additives on the microstructure and mechanical properties of A356 alloy. The authors reported on the formation of $\mathrm{Cr} /$ Zr-based intermetallics in precipitates with fish bone-like morphologies.

Quality index is a pivotal concept originally developed by Drouzy, Jacob, and Richard [29] who introduced an empirical parameter $Q$ or quality index, to characterize the mechanical performance of $\mathrm{Al}-7 \% \mathrm{Si}-\mathrm{Mg}$ casting alloys. They related the quality index $Q$ to the tensile strength, UTS, and the plastic strain of the material to fracture, $S_{f}$, as represented by the following equation:

$$
Q=U T S+d \log (S f) .
$$

Although the concept was developed specifically for alloys 356 and 357, it has occasionally been applied to other alloy systems as well [30-32]. A number of studies on Al-Cu$\mathrm{Mg}$-Ag alloys, however, showed that in contrast with the linear behavior of alloy 356 , a plot of UTS vs. $S_{\mathrm{f}}$ describes a curvilinear contour if the material has undergone aging, as was the case for alloy 201. The Cáceres model assumes that the material can be described applying Holloman's equation:

$$
\sigma=K \varepsilon^{n}
$$

The $\boldsymbol{q}$ values used in the Cáceres model for the quality index charts make use of equation (5), in view of the fact that necking or localized deformation begins at maximum load, where the increase in stress due to a decrease in the crosssectional area of the tensile specimen becomes greater than the increase in the load-carrying ability of the metal as a result of strain-hardening. Equation (6) makes it possible to calculate the quality index from the tensile test results based solely on the knowledge of the value of $\boldsymbol{K}$ [30].

$$
\begin{aligned}
q & =\frac{\mathcal{E}_{\text {plastic }}}{\mathrm{n}}, \\
\mathrm{Q} & =\mathrm{UTS}+0.4 \mathrm{~K} \log \left(s_{f}\right) .
\end{aligned}
$$

The principal aim of the present research work is to investigate the effects of minor additions of nickel and 
zirconium on the strength of the cast aluminum alloy 354 at high temperatures.

In order to meet this goal, it is necessary to attain the following objectives:

(i) To determine the tensile properties of the alloys studied at room temperature, using the different aging conditions of temperature and time

(ii) To correlate the results obtained from the room temperature tests with the principal microstructural features observed in the corresponding alloy samples in order to analyze and understand the major parameters involved in the strengthening of alloy 354 at high temperatures

\section{Experimental Procedure}

The chemical composition in wt.\% of the as-received 354 alloy is listed in Table 1. In order to attain the objectives outlined previously, an experimental work plan was developed as follows:

(i) Castings to be made so as to obtain tension test bars for the 5 alloys investigated;

(ii) Heat treatment of all test bars produced is as follows:

(a) Solution heat treatment for $8 \mathrm{~h}$ at $495^{\circ} \mathrm{C}$;

(b) Quenching in warm water at $60^{\circ} \mathrm{C}$;

(c) Artificial aging at 6 temperatures covering a wide range of aging behavior on-going from under-, peak-, and over aging conditions for times ranging from 2 hours to 100 hours, as shown in Table 2;

(iii) Tensile testing of the heat-treated test bars.

The as-received alloy was melted in a $120-\mathrm{kg}$ capacity SiC crucible, using an electrical resistance furnace. The metal temperature was maintained at $780^{\circ} \mathrm{C}$ (to dissolve maximum $\mathrm{Zr}$ [33]), while the melt was degassed using pure, dry argon injected into the melt for $30 \mathrm{~min}$ by means of a rotating graphite impeller at $135 \mathrm{rpm}$. Grain refining and modification of the melt were, respectively, carried out using Al-5\% Ti-1\% B and Al-10\% Sr master alloys to obtain levels of $0.25 \% \mathrm{Ti}$ and $200 \mathrm{ppm} \mathrm{Sr}$ in the melt. It should be mentioned here that to minimize the oxidation of $\mathrm{Sr}$, the Al-Sr master alloy was added 5 minutes before the end of degassing.

Three samples for chemical analysis were also taken at the time of the casting; this was done at the beginning, in the middle, and at the end of the casting process to ascertain the exact chemical composition of each alloy. Table 3 lists the chemical analysis of the various alloys studied together with their respective codes, as obtained from samplings taken for this purpose from the corresponding melts used in this work.

The melt was poured into a preheated ASTM B-108 permanent mold (preheated to $460 \mathrm{o}$ C) to prepare test bars for the tensile tests. Each mold casting provides two tensile bars, each with a gauge length of $70 \mathrm{~mm}$ and a cross-sectional diameter of $12.7 \mathrm{~mm}$, as shown in Figure 1.
TABle 1: Chemical composition of the as-received 354 alloy.

\begin{tabular}{lc}
\hline Element & (wt.\%) \\
\hline $\mathrm{Si}$ & 9.1 \\
$\mathrm{Fe}$ & 0.12 \\
$\mathrm{Cu}$ & 1.8 \\
$\mathrm{Mn}$ & 0.0085 \\
$\mathrm{Mg}$ & 0.6 \\
$\mathrm{Al}$ & 87.6 \\
\hline
\end{tabular}

As will be mentioned in a later subsection, heat treatment of the test bars used for tensile testing involves solution heat treating them at $495 \mathrm{oC}$ for $8 \mathrm{~h}$ (to avoid incipient melting [34]), followed by quenching in warm water at 60 oC, after which artificial aging is applied according to the plan established in Table 2. After aging, the test bars are allowed to cool naturally at room temperature $\left(25^{\circ} \mathrm{C}\right)$. All heat treatments are carried out in a Lindberg Blue $M$ air forced electric resistance furnace.

All of the samples, whether as-cast, solution heat-treated, or aged, were tested at $25 \underline{\mathrm{o}} \mathrm{C}$ to the point of fracture using an MTS servo-hydraulic mechanical testing machine at a strain rate of $4 \times 10^{-4} \mathrm{~s}^{-1}$. The yield strength (YS) was calculated according to the standard $0.2 \%$ offset strain, and the fracture elongation was calculated as the percent elongation (\%E1) over the $50 \mathrm{~mm}$ gauge length, as recorded by the extensometer. The ultimate tensile strength (UTS) was also obtained from the data acquisition system of the MTS machine. This machine was calibrated anew each time any testing was carried out. The average \%E1, YS, or UTS values obtained from the 10 samples tested (using bars with standard deviation \pm 5 ) where at least 7 bars were considered to determine the properties representing a specific condition.

Porosity percentage was determined using an image analyzer whereas determination of percentage of intermetallics as well as phase identification was carried out using electron probe microanalysis (EPMA) in conjunction with wavelength dispersive spectroscopic (WDS) analysis, using a JEOL combined microanalyzer operating at $20 \mathrm{kV}$ and $30 \mathrm{nA}$, where the electron beam size was $\sim 2 \mu \mathrm{m}$. Mapping of certain specific areas of the polished sample surfaces was also carried out where required, to show the distribution of different elements within the phases.

\section{Results and Discussion}

3.1. Microstructure Characterization. Figure 2(a) presents the microstructure of alloy $\mathrm{A}$ in the as-cast condition showing a large amount of $\mathrm{Al}_{2} \mathrm{Cu}$ phase as confirmed by the EDS spectrum displayed in Figure 2(b) corresponding to the white circled area in Figure 2(a). Figure 2(c) is a high magnification image of Figure 2(a) revealing the coexistence of the quaternary $\mathrm{Al}_{4} \mathrm{Mg}_{8} \mathrm{Cu}_{2} \mathrm{Si}_{6}$ phase with the $\mathrm{Al}_{2} \mathrm{Cu}$ phase in addition to precipitation of fine $\mathrm{B}-\mathrm{Al}_{5} \mathrm{FeSi}$ phase platelets. Solutionizing at $495^{\circ} \mathrm{C}$ for $8 \mathrm{~h}$ was proven to be effective in dissolving most of the $\mathrm{Cu}$-containing phase with traces of insoluble $\mathrm{Al}-\mathrm{Fe}-\mathrm{Cu}$ and $\mathrm{B}-\mathrm{Fe}$ as shown in Figure 2(d).

The microstructure of alloy $F$ (containing $0.4 \% \mathrm{Ni}+0.4 \%$ $\mathrm{Zr}$ ) is shown in Figure 3(a). As can be seen from Table 3, the 
TABLE 2: Artificial aging conditions used for room temperature tension tests.

\begin{tabular}{lccccccccccccc}
\hline \multirow{2}{*}{ Temperature $\left({ }^{\circ} \mathrm{C}\right)$} & \multicolumn{10}{c}{ Aging time $(h)$ and aging condition codes } \\
& 2 & 4 & 6 & 8 & 10 & 12 & 16 & 20 & 24 & 36 & 48 & 72 & 100 \\
\hline 155 & 1 & 2 & 3 & 4 & 5 & 6 & 7 & 8 & 9 & 10 & 11 & 12 & 13 \\
170 & 14 & 15 & 16 & 17 & 18 & 19 & 20 & 21 & 22 & 23 & 24 & 25 & 26 \\
190 & 27 & 28 & 29 & 30 & 31 & 32 & 33 & 34 & 35 & 36 & 37 & 38 & 39 \\
240 & 40 & 41 & 42 & 43 & 44 & 45 & 46 & 47 & 48 & 49 & 50 & 51 & 52 \\
300 & 53 & 54 & 55 & 56 & 57 & 58 & 59 & 60 & 61 & 62 & 63 & 64 & 65 \\
350 & 66 & 67 & 68 & 69 & 70 & 71 & 72 & 73 & 74 & 75 & 76 & 77 & 78 \\
\hline
\end{tabular}

TABLE 3: Chemical composition of the alloys used in this work (wt.\%).

\begin{tabular}{lcccccccrrr}
\hline Alloy/element & $\mathrm{Si}$ & $\mathrm{Fe}$ & $\mathrm{Cu}$ & $\mathrm{Mn}$ & $\mathrm{Mg}$ & $\mathrm{Ti}$ & $\mathrm{Sr}$ & $\mathrm{Ni}$ & $\mathrm{Zr}$ & $\mathrm{Al}$ \\
\hline$A$ & 9.43 & 0.08 & 1.85 & 0.01 & 0.49 & 0.22 & 0.0150 & $\sim$ & $\sim$ \\
$D$ & 9.16 & 0.08 & 1.84 & 0.01 & 0.49 & 0.22 & 0.0149 & $\mathbf{0 . 4 6}$ & $\sim$ \\
$E$ & 9.10 & 0.07 & 1.83 & 0.00 & 0.45 & 0.21 & 0.0145 & $\sim$ & $\mathbf{0 . 3 9}$ \\
$F$ & 9.10 & 0.08 & 1.86 & 0.00 & 0.46 & 0.22 & 0.0122 & $\mathbf{0 . 4 0}$ & $\mathbf{0 . 3 9}$ & 87.7 \\
$G$ & 9.01 & 0.08 & 1.85 & 0.00 & 0.45 & 0.21 & 0.0127 & $\mathbf{0 . 2 1}$ & $\mathbf{0 . 1 9 0}$ & 87.8 \\
\hline
\end{tabular}

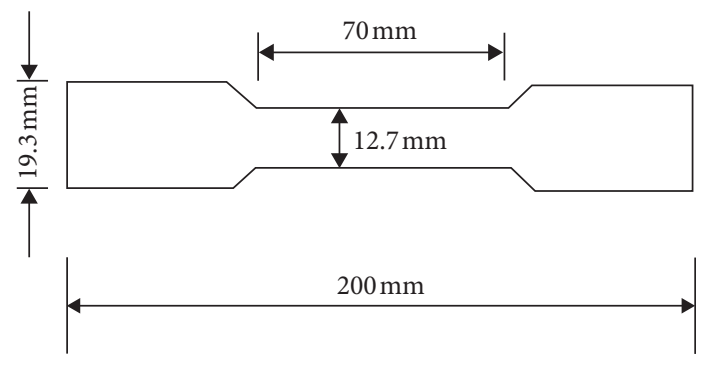

Figure 1: Measurements of the tensile tests.

amount of precipitated intermetallics has noticeably increased. Figure $3(\mathrm{~b})$ is a high magnification image of Figure 3 (a) revealing precipitation of a Ni-containing phase in the form of short platelets. Figures 3(c) and 3(d) are X-ray images of the distribution of $\mathrm{Ni}$ and $\mathrm{Zr}$ within the platelets indicating that these platelets are the $(\mathrm{Al}, \mathrm{Si})_{3}(\mathrm{Ni}, \mathrm{Zr}, \mathrm{Fe})$ phase reported by Jo et al. [26]. The composition of these platelets is presented in Table 4. Figure 3(e) illustrates the fracture surface of alloy $E$ showing precipitation of a large $\mathrm{Zr}$-Ti intermetallic during solidification of the alloy.

Table 5 summarizes secondary dendrite arm spacing SDAS, grain size, porosity \%, and volume fraction of intermetallics for alloys $A$ through $G$ (samples were prepared from the tensile test bars, $10 \mathrm{~mm}$ below the fracture surface). Since all alloys were grain refined using Al-5\%Ti-1\%B master alloy, the grain size revealed noticeable variation from one alloy to another reaching about $40 \%$ reduction in the case of alloy E. Similarly, the secondary dendrite arm spacing values did not vary much as the solidification rate was about $8^{\circ} \mathrm{C} / \mathrm{s}$ in all cases. The difference noted in the amount of intermetallics after solution heat treatment is mainly due to dissolution of $\mathrm{Al}_{2} \mathrm{Cu}$ phase as illustrated in Figures 4(a) and 4(d), where Figure 4 demonstrates the variation in the size and density of the precipitated hardening phase $\left(\mathrm{Al}_{2} \mathrm{Cu}\right.$ phase in the present case) with the increase in aging temperature from ultra-fine particles at $170^{\circ} \mathrm{C}$ (Figure 4(b)-peak aging) to rod-shaped particles at $350^{\circ} \mathrm{C}$ (Figure $4(\mathrm{~d})$-over aging) indicating the possibility of the commencement of incoherency.

3.2. Tensile Properties. In this section, the tensile properties of the present alloys following aging treatment at $155^{\circ} \mathrm{C}$ (under aging), $190^{\circ} \mathrm{C}$ (peak aging), and $350^{\circ} \mathrm{C}$ (over aging) will be discussed. The results are presented in Figures 5-7. In spite of the relatively low solution heat treatment temperature of 495 oC used for the purposes of this work, increased strength after the treatment is normally to be observed in similar 354 alloys which use a solution heat treatment temperature of $525 \underline{\mathrm{o}} \mathrm{C}$ for $2-3 \mathrm{~h}$ period [32-38]. This selected temperature for the solution heat treatment might appear to be overconservative, but it was deemed necessary to avoid the risk of any incipient melting of the copper phases, which could have the potential for deteriorating the mechanical properties of the alloys to a great extent.

The strength values, particularly the UTS, increased by as much as 30 pct between the as-cast (AC) and the solution heat-treated (SHT) conditions. This increase in the mechanical properties is related to the changes occurring in the form of the silicon particles which become more rounded, decreasing their aspect ratio and density. Through solution heat treatment and artificial aging, the strength of alloy $A$ was increased by $\sim 64 \%$ over its as-cast strength. From the tensile properties as shown in Figures 5-7, the maximum value for UTS of $\sim 386 \mathrm{MPa}$ may be obtained with two different sets of aging conditions, i.e., $155^{\circ} \mathrm{C} / 100 \mathrm{hrs}$ and $190^{\circ} \mathrm{C} / 2$ hrs. The greatest mechanical stability for the aging treatments was observed at $155^{\circ} \mathrm{C}$. Even though a significant decrease in the alloy strength is not in evidence from 2 to 100 hours at $350^{\circ} \mathrm{C}$, nonetheless, the greatest mechanical deterioration will be observed after less than 2 hours of aging treatment. This previous assumption is based on a consideration of the tensile properties of the material upon solution 


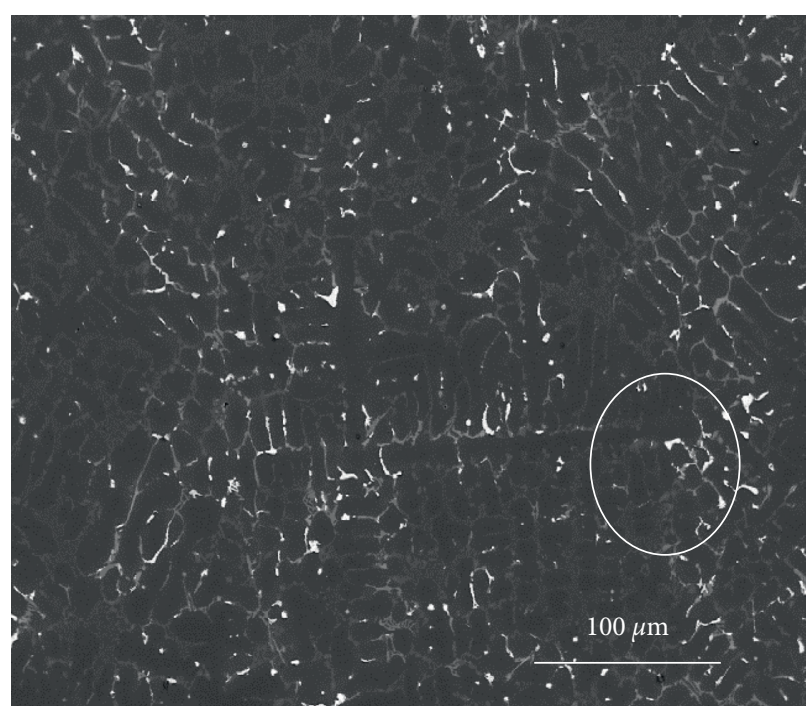

(a)

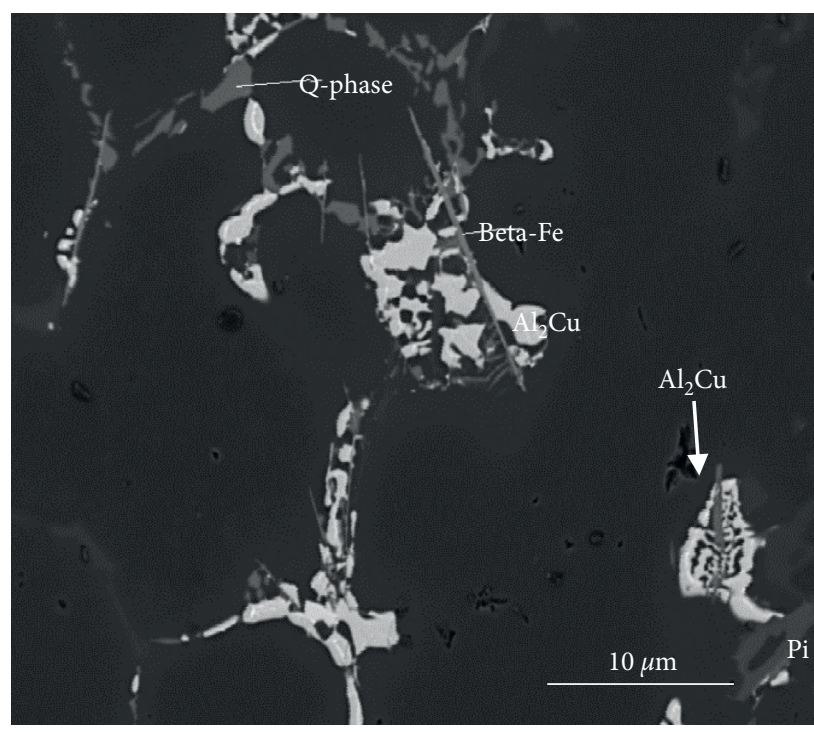

(c)

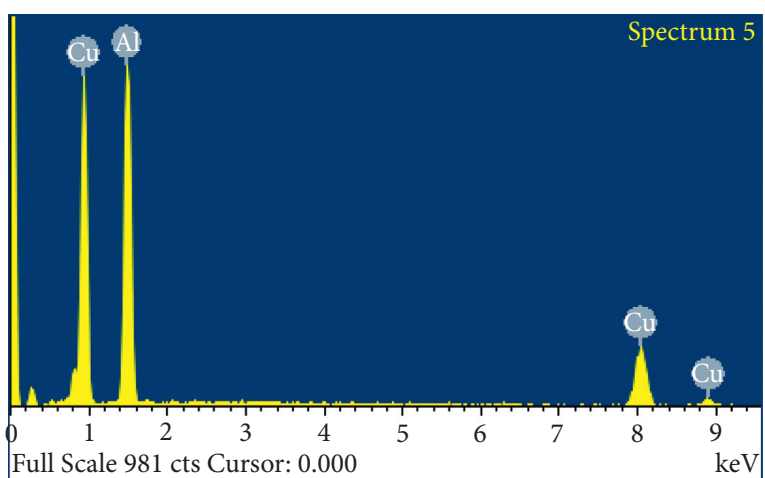

(b)

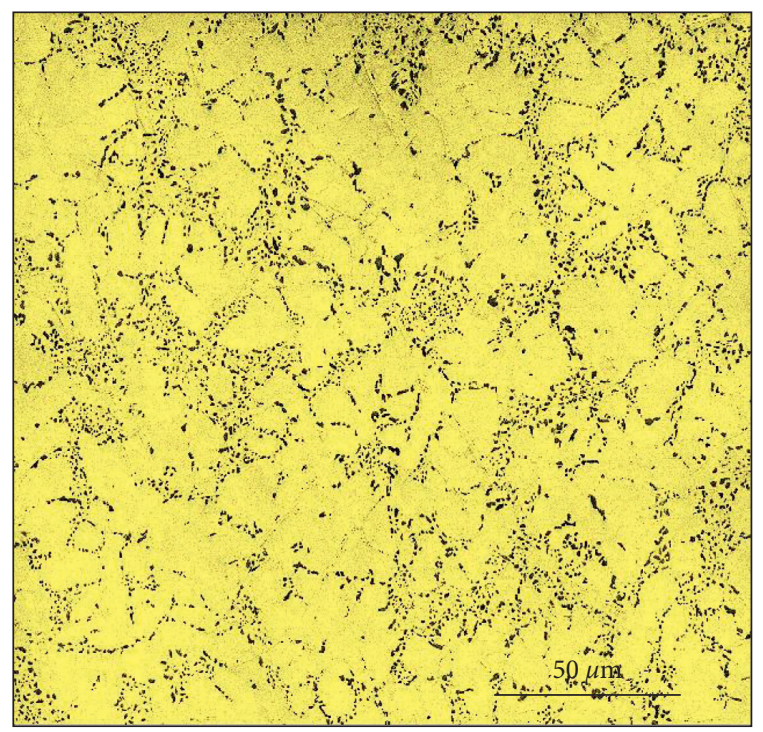

(d)

Figure 2: Microstructure of the base alloy $(A)$ : (a) backscattered electron image of alloy $A$ in the as-cast condition, (b) EDS spectrum corresponding to (a), (c) high magnification image of (a), and (d) alloy $A$ following solutionizing at $495^{\circ} \mathrm{C} / 8 \mathrm{~h}$.

heat treatment, namely, UTS $=305 \mathrm{MPa}$ and YS $=161 \mathrm{MPa}$, implying that the over aged samples tended to lose between $15 \%$ and $40 \%$ of their original strength within the first 2 hours of being subjected to aging at $350^{\circ} \mathrm{C}$.

Considering the yield strength in the solution heattreated condition, in conjunction with the artificial aging conditions used, it was possible to increase the yield strength value by more than $100 \mathrm{pct}$. The maximum yield strength was reached after 100 hours at the aging temperature of $155^{\circ} \mathrm{C}$ and after 2 hours at 190 o C. The yield strength behavior appears to be most stable at $190^{\circ} \mathrm{C}$ aging temperature, showing a variation of $50 \mathrm{MPa}$ in yield strength values for aging times between 2 and 100 hours. These observations were taken into account for the selection of this specific temperature for experiments designed to investigate how the mechanical properties may be affected by long exposure times.

The general behavior of alloy $A$ with regard to ductility displays a decrease from $155^{\circ} \mathrm{C}$ to $190^{\circ} \mathrm{C}$. A lower ductility value is observed for the condition involving $190^{\circ} \mathrm{C}$ for 10 hours. The greatest ductility values may be observed for aging at $350^{\circ} \mathrm{C}$ although none of the aging conditions reaches the higher ductility values shown in the solution heat-treated condition. This observation may be considered as evidence that the mechanical behavior displayed by alloy $A$ is common to that of the Al-Si-Cu-Mg alloys whose strength is obtained at the expense of ductility $[39,40]$.

The YS values for alloys $A$ and $D$ at aging temperatures of $155^{\circ} \mathrm{C}$ and $350^{\circ} \mathrm{C}$ represent the extreme ends of the range of aging temperatures used for these alloys. A decrease in yield 


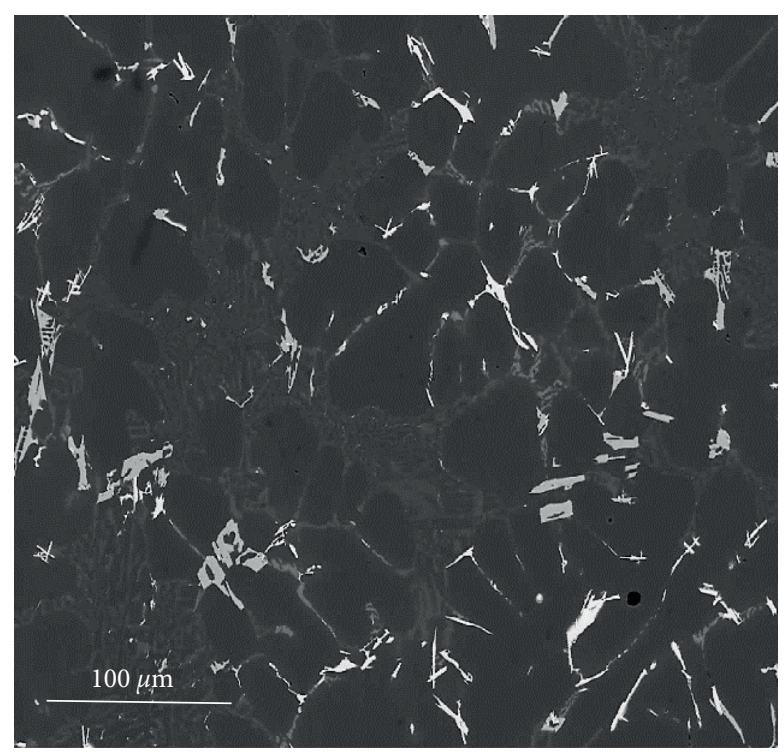

(a)

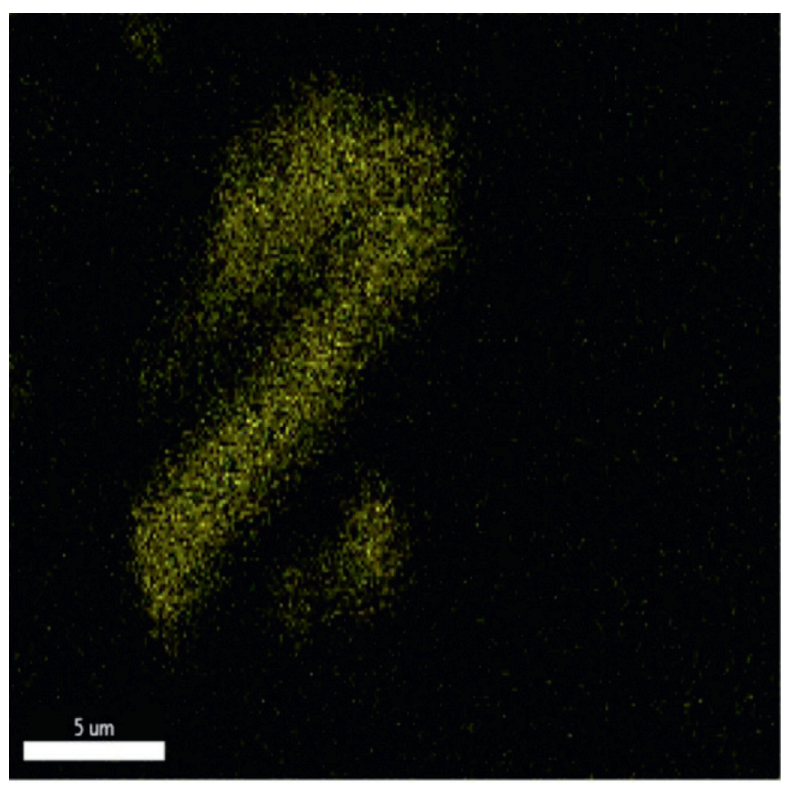

(c)

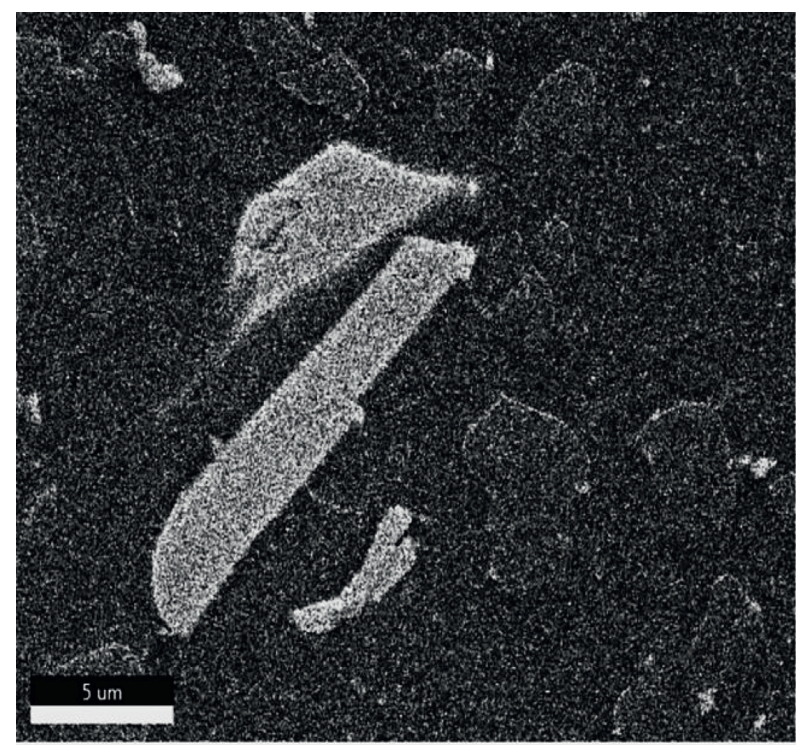

(b)

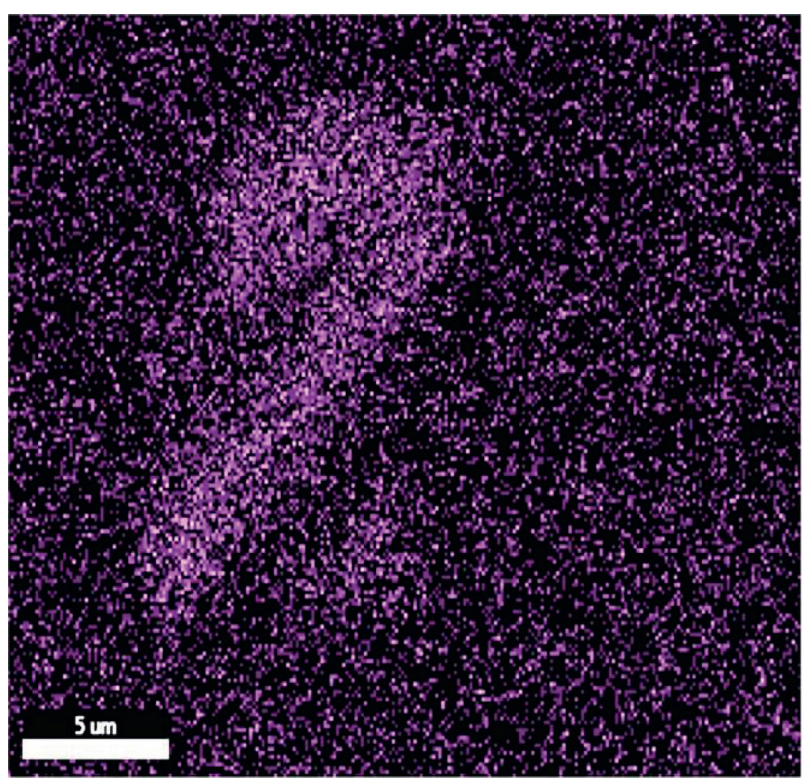

(d)

FIgURE 3: Continued. 


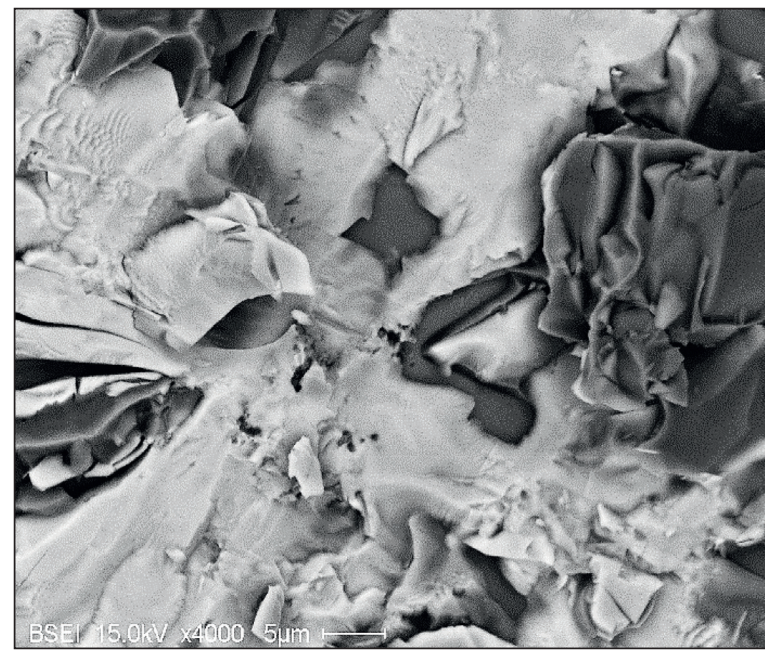

(e)

Figure 3: Microstructure of alloy $F$ in the as-cast condition: (a) backscattered electron micrograph, (b) a high magnification of (a), (c) X-ray image of Ni distribution, (d) X-ray image of $\mathrm{Zr}$ distribution, and (e) fracture surface of alloy $E$ in the as-cast condition.

TABle 4: Chemical composition corresponding to Figure 3(e).

\begin{tabular}{lccccccccc}
\hline Element & Weight $\%$ & Atomic $\%$ & Net int. & Error \% & K ratio & $Z$ & $R$ & $A$ & $F$ \\
\hline MgK & 0.46 & 0.63 & 18.61 & 17.63 & 0.00 & 1.1 & 0.96 & 0.69 & 1.02 \\
$\mathrm{AlK}$ & 58.29 & 71.88 & $2,505.57$ & 3.62 & 0.49 & 1.06 & 0.97 & 0.8 & 1 \\
$\mathrm{SiK}$ & 10.47 & 12.40 & 300.61 & 6.93 & 0.06 & 1.08 & 0.97 & 0.55 & 1.01 \\
$\mathrm{ZrL}$ & 14.74 & 5.38 & 199.37 & 6.30 & 0.09 & 0.81 & 1.15 & 0.74 & 1.01 \\
$\mathrm{ScK}$ & 0.31 & 0.23 & 5.37 & 59.34 & 0.00 & 0.94 & 1.02 & 0.92 & 1.04 \\
$\mathrm{TiK}$ & 5.58 & 3.88 & 88.02 & 5.55 & 0.05 & 0.92 & 1.02 & 0.95 \\
$\mathrm{NiK}$ & 6.87 & 3.90 & 35.96 & 10.53 & 0.07 & 0.91 & 1.03 & 0.99 \\
$\mathrm{CuK}$ & 3.28 & 1.72 & 12.65 & 25.82 & 0.03 & 0.86 & 1.03 & 1 \\
\hline
\end{tabular}

TABLE 5: SDAS, grain size, porosity \%, level of modification, and volume fraction of intermetallics for alloys $A, D, E, F$, and $G$.

\begin{tabular}{|c|c|c|c|c|c|c|}
\hline \multirow[t]{2}{*}{ Alloy code condition } & \multirow{2}{*}{$\begin{array}{c}\text { SDAS }(\mu \mathrm{m}) \\
\text { Av }\end{array}$} & \multirow{2}{*}{$\begin{array}{c}\text { Grain size }(\mu \mathrm{m}) \\
\text { Av }\end{array}$} & \multicolumn{2}{|c|}{ Porosity (\%) } & \multicolumn{2}{|c|}{$\begin{array}{l}\text { Volume fraction of } \\
\text { intermetallics (\%) }\end{array}$} \\
\hline & & & Av & SD & Av & $\mathrm{SD}$ \\
\hline $\mathrm{A}-\mathrm{AC} *$ & 19.3 & 201 & 0.135 & 0.06 & 3.08 & 0.32 \\
\hline A-SHT & 23.1 & 192 & 0.12 & 0.05 & 1.27 & 0.13 \\
\hline $\mathrm{D}-\mathrm{AC}$ & 18.2 & 186 & 0.121 & 0.07 & 4.22 & 0.35 \\
\hline D-SHT & 18.6 & 184 & 0.122 & 0.06 & 2.76 & 0.47 \\
\hline E-AC & 18.9 & 122 & 0.11 & 0.05 & 4.23 & 0.40 \\
\hline E-SHT & 19.9 & 116 & 0.108 & 0.04 & 2.86 & 0.43 \\
\hline $\mathrm{F}-\mathrm{AC}$ & 19 & 94 & 0.11 & 0.05 & 5.02 & 0.43 \\
\hline F-SHT & 21 & 96 & 0.111 & 0.06 & 3.74 & 0.31 \\
\hline G-AC & 25.3 & 125 & 0.12 & 0.03 & 3.57 & 0.23 \\
\hline G-SHT & 21.2 & 111 & 0.13 & 0.04 & 2.03 & 0.34 \\
\hline
\end{tabular}

$* \mathrm{AC}$ : as cast.

strength as a result of the addition of nickel is noted at the aging temperature of $155 \underline{0} \mathrm{C}$, of the order of $20 \mathrm{MPa}$. In contrast, no appreciable difference in the YS values is observed between alloys $D$ and $A$ at the $350^{\circ} \mathrm{C}$ aging temperature. This decrease in strength through the addition of nickel is related to the interaction between copper and nickel to form precipitates of $\mathrm{Al}_{3} \mathrm{CuNi}$ in the microstructure. The
$\mathrm{Al}_{3} \mathrm{CuNi}$ phase was detected in alloys containing nickel, namely, alloys $D, F$, and $G$. Since copper, as well as magnesium, determines the precipitation strengthening of the $\mathrm{Al}-\mathrm{Si}$-Cu-Mg alloys, the available copper would form $\mathrm{Al}_{2} \mathrm{Cu}$ precipitates through the solution heat treatment/quenching/ aging process, thereby strengthening the cast alloys. The formation of $\mathrm{Al}-\mathrm{Cu}-\mathrm{Ni}$ precipitates would thus subtract part 


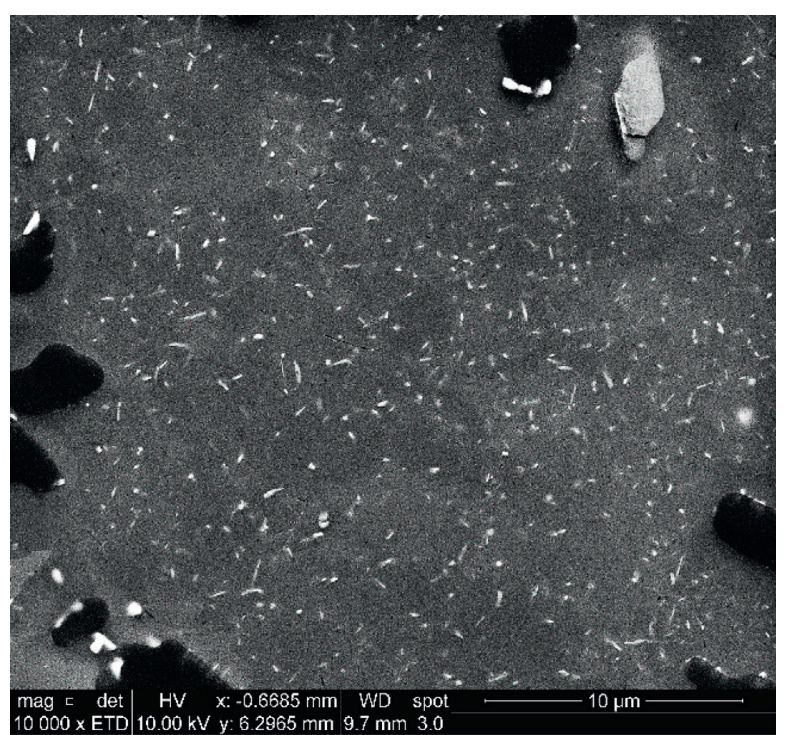

(a)

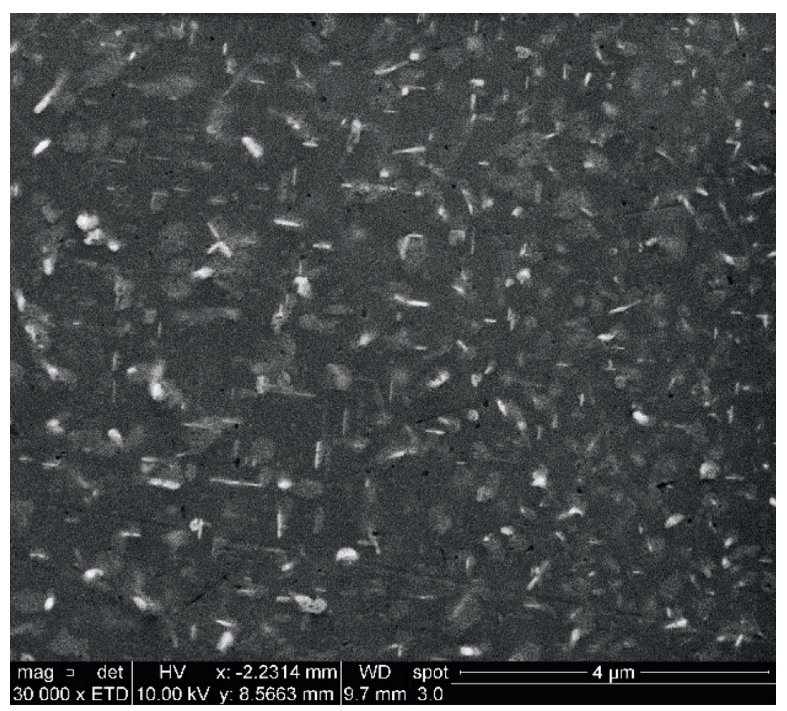

(c)

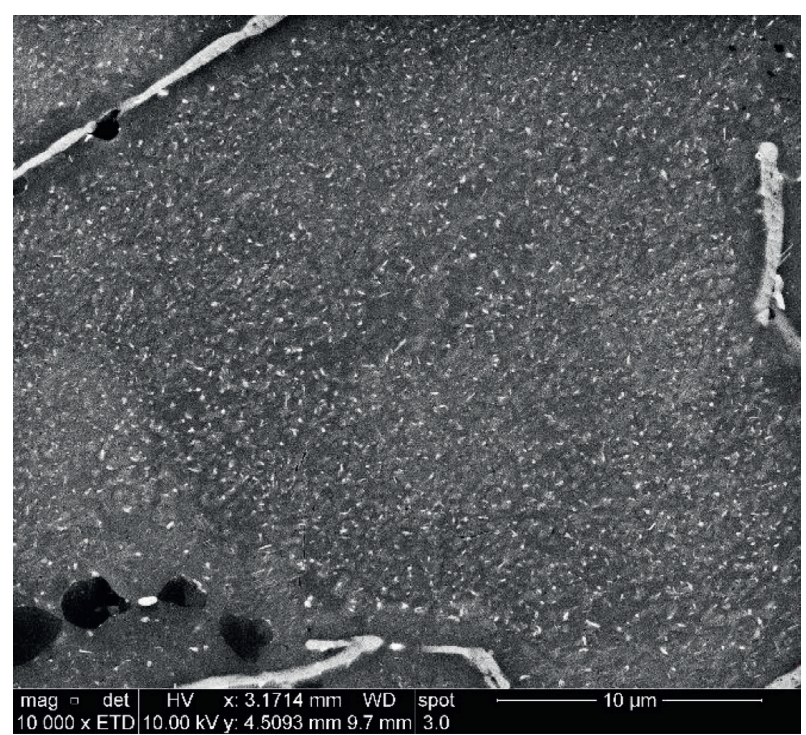

(b)

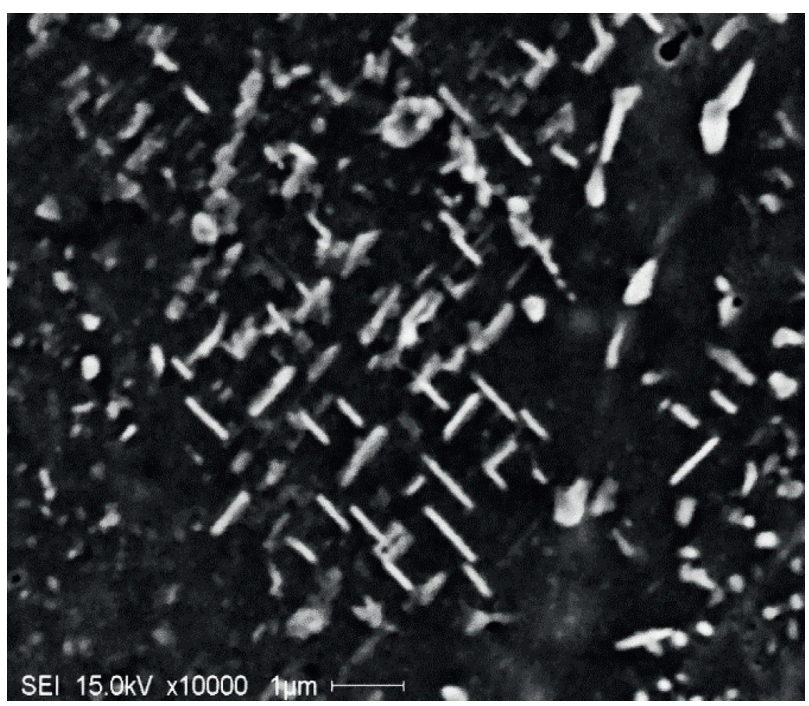

(d)

FIgURe 4: Development of precipitation-hardening $\mathrm{Al}_{2} \mathrm{Cu}$ phase in alloy $A$ during $2 \mathrm{~h}$ aging at (a) $155^{\circ} \mathrm{C}$, (b) $170^{\circ} \mathrm{C}$, (c) $240^{\circ} \mathrm{C}$, and (d) $350^{\circ} \mathrm{C}$.

of the copper content available for strengthening; this is the principal reason for which a slight decrease in YS is observed with the addition of 0.4 wt.\% nickel.

With regard to the base alloy $A$ and alloy $D$, the maximum strength is reached at low aging temperatures ranging from $155 \underline{0}$ C to 190 oC, showing a decrease in ductility with the increase in strength; it should be noted that this is the expected behavior for Al-Si-Cu-Mg alloys [41-45]. It will also be observed that, at low aging temperatures, the effect of intermetallics in the reduction of ductility is more pronounced than it is at high aging temperatures of 350 oC. The increase in ductility at an aging temperature of $190 \underline{\mathrm{o}} \mathrm{C}$, or more, becomes evident since the alloy softens and the effect of the intermetallics on ductility seems attenuated.

From Figure 6, it is observed that alloy E, containing 0.4 wt.\% Zr, does not show any significant change in YS, when compared with the base alloy $A$. The decrease in the ductility of alloy $E$ with respect to alloy $A$ may be assimilated by observing Table 5 where the level of insoluble intermetallics increases from 1.27 to $2.86 \%$, between the base alloy and alloy $E$, respectively. This behavior may also be seen for the long-exposure-time at the aging temperature of 190 oC. In general terms, there is no appreciable increase in strength (UTS and YS) to be observed in alloy $E$ containing 0.4 wt.\% $\mathrm{Zr}$ although there is, however, a visible decrease in ductility which is greater than $20 \%$ for nearly all of the tests performed.

To understand the latter observation, it is necessary to consider three characteristics observed from the microstructural analysis of alloy $E$. Firstly, the amount of insoluble intermetallic phases increased from $1.27 \%$ in the base alloy to $2.86 \%$ in alloy $E$. Secondly, the grain size was reduced from $200 \mu \mathrm{m}$ in alloy $A$ to $120 \mu \mathrm{m}$ in alloy $E$. Both arguments could indicate that $\mathrm{Zr}$ available for strengthening was used to 


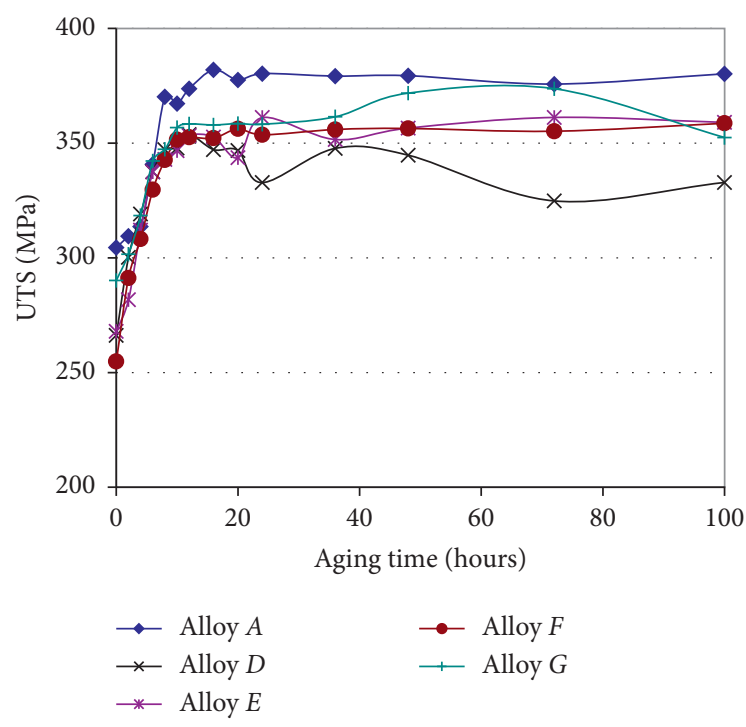

(a)

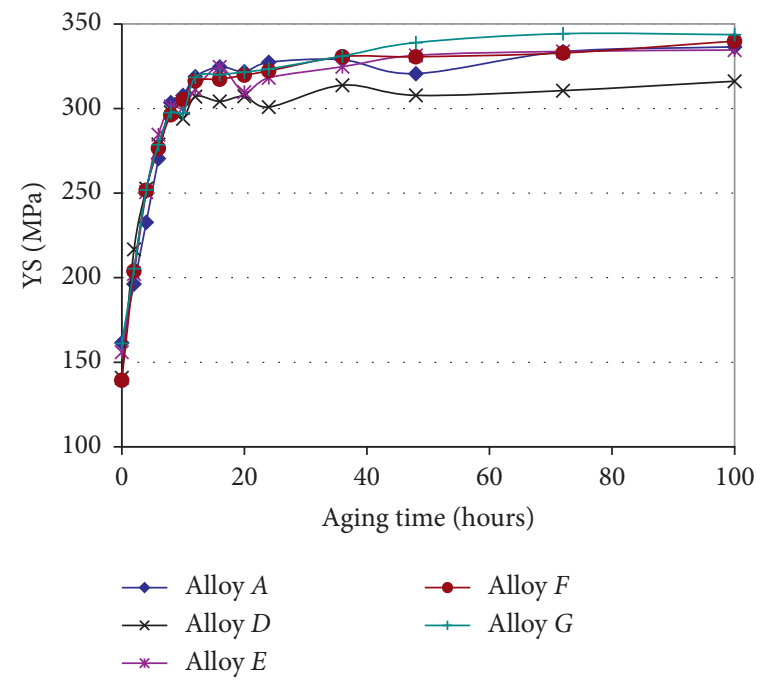

(b)

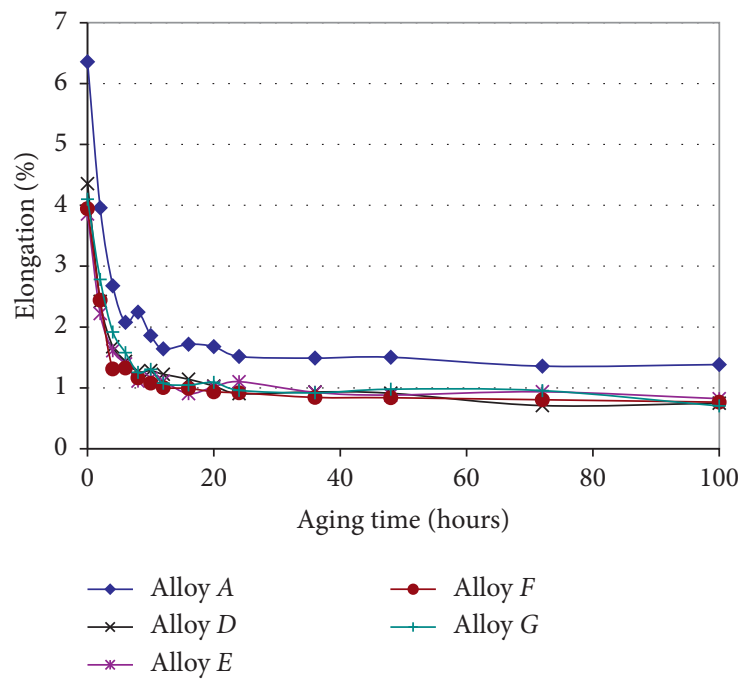

(c)

FIGURE 5: Variation of the tensile properties as a function of aging at $155^{\circ} \mathrm{C}$ for times up to $100 \mathrm{~h}$ : (a) UTS, (b) YS, and (c) \%El. Same legends as in Figure 5(a).

form large intermetallics in the form of $(\mathrm{Al}, \mathrm{Si})_{3}(\mathrm{Zr}, \mathrm{Ti})$ phases, as well as to reduce the grain size. Finally, a third aspect which should be taken into consideration is that during the casting procedures, the temperature of the melt was maintained at $780^{\circ} \mathrm{C}$, implying that $\mathrm{Zr}$ added in the form of $\mathrm{Al}-20 \% \mathrm{Zr}$ master alloy may not be capable of dissolving completely; this is due to the fact that, with $0.4 \mathrm{wt} . \% \mathrm{Zr}$, the $\mathrm{Al}-\mathrm{Zr}$ phase diagram indicates the liquidus temperature at $780^{\circ} \mathrm{C}[41]$.

As a result of examining the negative effects of nickel on the strength of alloy $E$, it becomes relevant to discuss why the addition of nickel did not reduce the yield strength in alloy $F$ which contains $0.4 \mathrm{wt} . \% \mathrm{Ni}$ plus $0.4 \mathrm{wt}$ \% $\% \mathrm{Zr}$. With regard to intermetallics, our earlier studies [46-48] show the precipitation of $(\mathrm{Al}, \mathrm{Si})_{3}(\mathrm{Zr}, \mathrm{Ti})$ phase with the Ni-rich phase $\mathrm{Al}_{9} \mathrm{NiFe}$ adhering to it. The $\mathrm{Al}_{9} \mathrm{NiFe}$ phase was observed in the microstructure of tensile samples, as well as phases which appear similar to the Ni-rich phase were observed to adhere to the $\mathrm{Zr}$-rich phases in the microstructures of the tensile samples of alloy $F$ as demonstrated in Figure 3. These observations may suggest that the copper did not significantly interact with the nickel to form $\mathrm{Al}_{3} \mathrm{CuNi}$ phases, and as a result, the copper was free to strengthen alloy $F$, in the same way as the copper was able to strengthen alloy $A$.

Ductility seems to be affected principally at low aging temperatures of $155^{\circ} \mathrm{C}$ through $190^{\circ} \mathrm{C}$. This decrease in ductility may be interpreted by noting that alloy $F$ had the greatest amount of insoluble phases as listed in Table 5; these would then act as stress concentrators during flow stress, thereby limiting the ductility in alloy $F[49,50]$.

Alloy $\mathrm{G}$, containing $0.2 \mathrm{wt} . \% \mathrm{Zr}$ and $0.2 \mathrm{wt} . \% \mathrm{Ni}$, displays greater strength than alloy $E$, which contains $0.4 \mathrm{wt} . \% \mathrm{Zr}$, or greater even than alloy $F$, which contains 0.4 wt.\%. Zr plus 0.4 wt.\% Ni. According to the Al-Zr phase diagram [41], with 


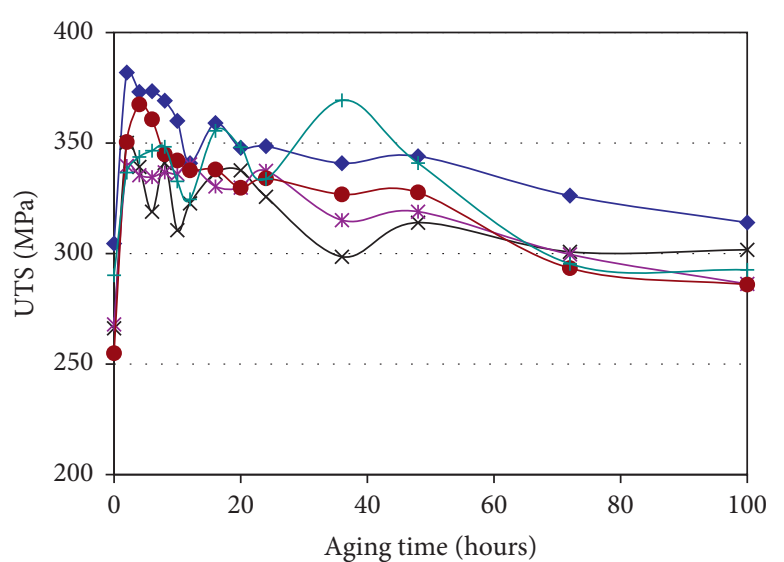

(a)

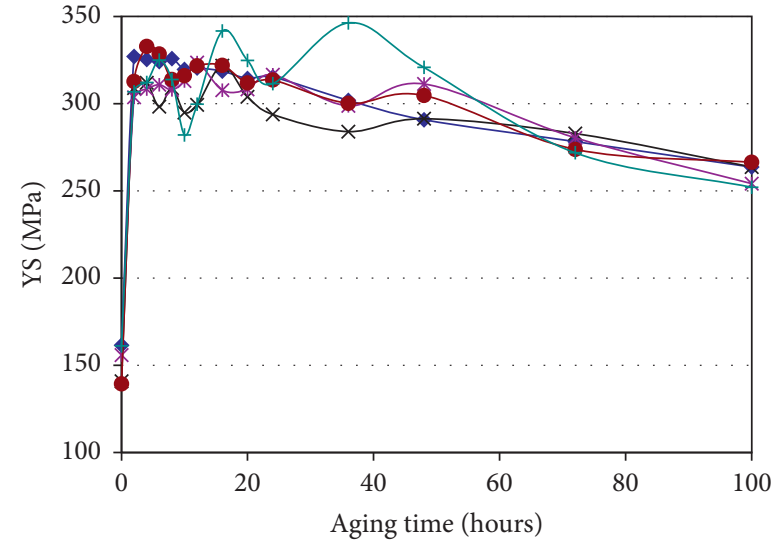

(b)

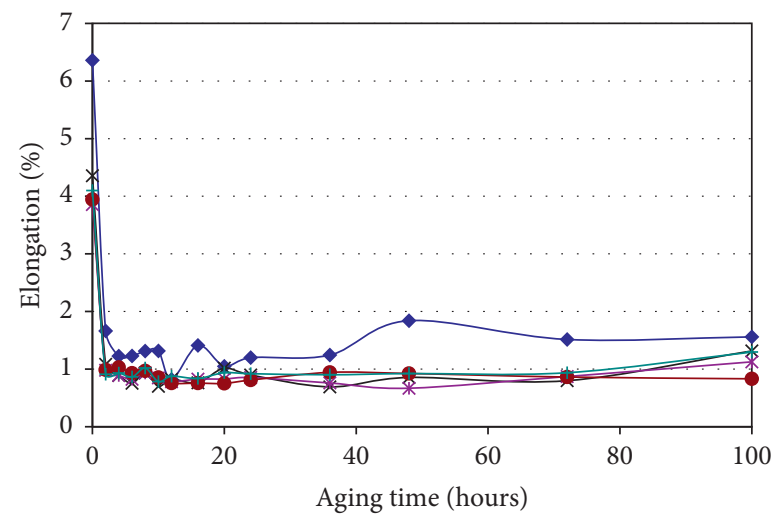

(c)

FIgURE 6: Variation of the tensile properties as a function of aging at $190^{\circ} \mathrm{C}$ for times up to $100 \mathrm{~h}$ : (a) UTS, (b) YS, and (c) \% El. Same legends as in Figure 5(a).

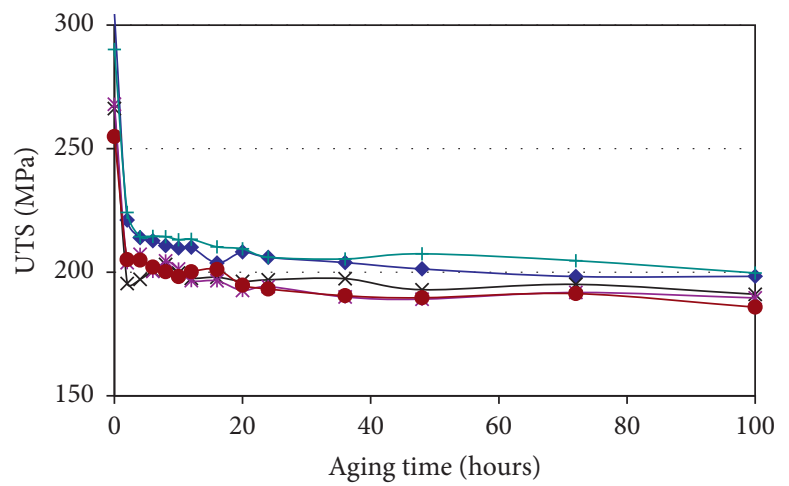

(a)

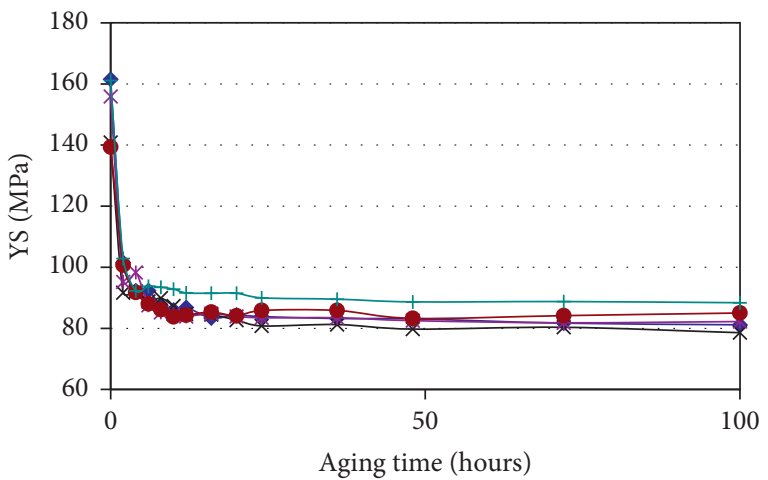

(b)

Figure 7: Continued. 


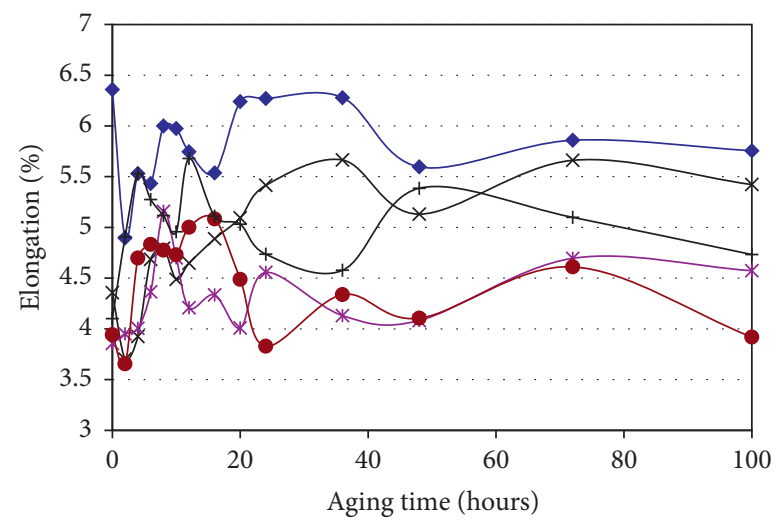

(c)

FigURE 7: Variation of the tensile properties as a function of aging at $350^{\circ} \mathrm{C}$ for times up to $100 \mathrm{~h}$ : (a) UTS, (b) YS, and (c) \% El. Same legends as in Figure 5(a).

0.2 wt.\% $\mathrm{Zr}$ content, the liquidus temperature is approximately $720^{\circ} \mathrm{C}$. Taking into consideration that, during casting procedures, the temperature of the melt was maintained at $780^{\circ} \mathrm{C}$, it is fairly likely that the added $\mathrm{Zr}$ dissolved completely which is essential for strengthening the alloys by means of $\mathrm{Zr}$-rich precipitates [51, 52]. As may be seen from Figure 6, alloy $G$ is the only alloy which shows an increase in strength in comparison with alloy $A$. In fact, even at the aging temperature of $350^{\circ} \mathrm{C}$, the strength values are observed to be greater than those obtained with the base alloy.

Figure 8 depicts an example of the tensile properties obtained for the five studied alloys at $170^{\circ} \mathrm{C}$ relative to the values obtained for the $A$ base alloy in the as-cast condition, i.e., subtracting the values obtained for the base alloy $A$ in each case and plotted as $\triangle P$ values on the $Y$-axis $(P=$ property $=\mathrm{YS}$, UTS or $\% \mathrm{El}$ ), with the $X$-axis representing the aging time (see Supplementary Materials for $155^{\circ} \mathrm{C}$ and $350^{\circ} \mathrm{C}$ aging temperatures). This approach helps to better visualize the effects and interactions of the various additions used and the different heat treatment conditions, so as to arrive at a better understanding of the effects of $\mathrm{Ni}$ and $\mathrm{Zr}$ on the tensile properties of 354 casting alloys. As may be seen from Figure 8, additions of these elements improve the alloy performance, i.e., the tensile properties at $170^{\circ} \mathrm{C}$. Figure 8 (a) shows that alloy $A$ exhibits the best contribution to UTS at all aging times. After $10 \mathrm{~h}$ aging time, the comparative UTS (or $\triangle \mathrm{P}_{\text {UTS }}$ ) values start to decrease as the aging time increases, indicating that these elements provide little or no improvement in mechanical properties. On the other hand, the comparative yield strength (or $\triangle \mathrm{P}_{\mathrm{YS}}$ ) values of all alloys are improved, as shown in Figure 8(b) and are stabilized after $8 \mathrm{~h}$ aging time, while Figure $8(\mathrm{c})$ shows that the $\triangle \mathrm{P}_{\% \mathrm{El}}$ or percent elongation to fracture values for all alloys is much lower than that of the $A$ base alloy, which is to be expected, in light of the results shown in Figure 8(a).

Figure 9 compiles the strength-ductility values obtained for all the 354 alloys investigated. These values fall into regions corresponding to peak aging, under aging, and over aging. Using regression analysis, the UTS versus \%El relationships may be expressed as follows:
UTS $=-38.26 x+408.1$ with a fit of $R^{2}=0.82$ (alloy $A$ )

UTS $=-45.0 x+373.0$ with a fit of $R^{2}=0.87$ (alloy $F$ )

It is evident that the slope of alloy $A$ is higher than that for alloy F. Also, the UTS levels are higher than those for alloy $F$ due to the higher volume fraction of intermetallics in the latter as noted from Table 5.

3.3. $Q$ Charts. This section will be limited to alloy $A$. The Cáceres method which is used here for constructing the quality index charts involves the use of a single value of the strength coefficient $(\boldsymbol{K})$ for all the conditions appearing in the charts. In order to obtain the values of $n$ and $\mathrm{K}$ described in equations (5) and (6), a series of stress-strain curves were used as shown in Figure 10, whereas their aging conditions are listed in Table 6 . Based on the analysis of these curves, the values of $\boldsymbol{n}=0.193$ and $\boldsymbol{K}=530$ were obtained. The reason for taking only 15 conditions out of a total of 80 was principally to avoid an overcrowded diagram. The curves were divided into three groups. The criterion applied for using these 15 conditions (including the as-cast and SHT conditions) was to take into consideration the extreme values, particularly those regarding the $\%$ elongation and yield strength values.

Figure 11(a) shows that the plastic strain and the quality index $(Q)$ both display a significant increase upon solution heat treatment in spite of the fact that the relative ductility (q) attains a value of 0.31 implying that alloy $A$ in its solution-treated condition has reached $31 \%$ of its maximum quality index value $(Q)$. When the ductility increases sharply from the as-cast to the solution heat-treated condition, such changes can be related to the spheroidization of silicon particles and to the uniformity of the microstructure in the solution heat-treated condition as illustrated in Figure 2(d). Figure 11(b) demonstrates the $Q$-chart for alloy $A$ aged at $155^{\circ} \mathrm{C}$ for times up to $100 \mathrm{~h}$. As can be seen, most of the points are falling in a narrow range of $Q(416-366 \mathrm{MPa})$. The maximum value of $Q$ was achieved after aging for $2 \mathrm{~h}$ with minimum UTS value of $308 \mathrm{MPa}$, and a minimum $Q$ value 


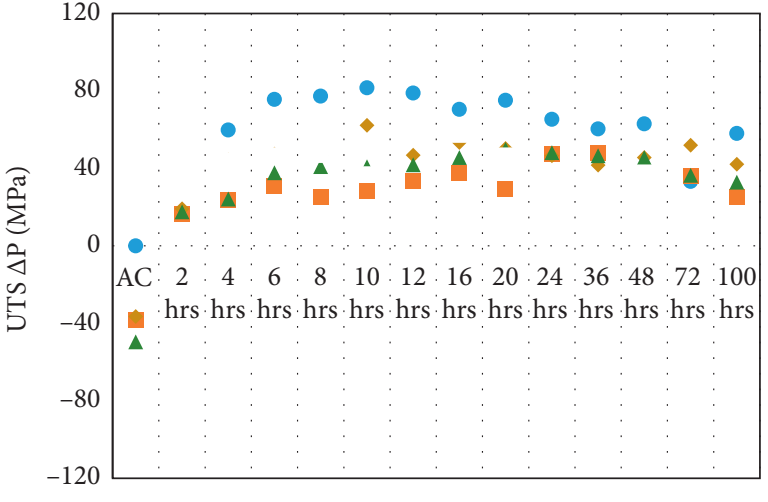

Aging time

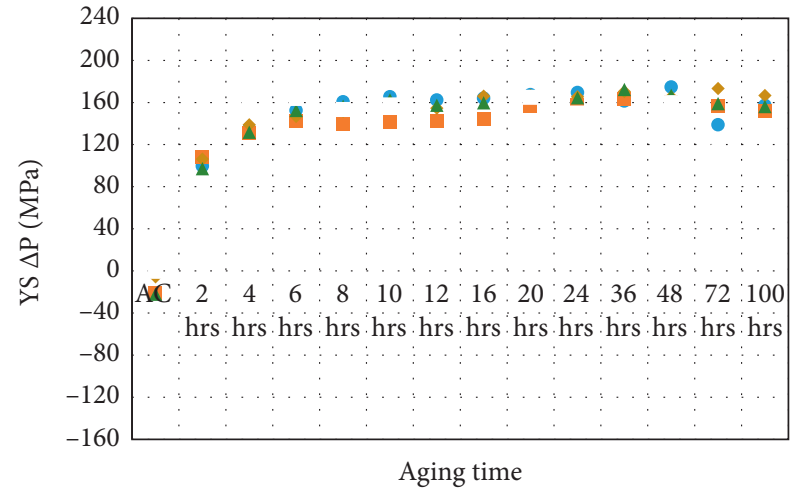

$\begin{array}{lr}\text { - Alloy } A & \text { Alloy } F \\ \text { - Alloy } D & \text { Alloy } G \\ \text { - Alloy } E & \end{array}$

(b) (a)

- Alloy $F$

Alloy $G$

- Alloy $D$

- Alloy E

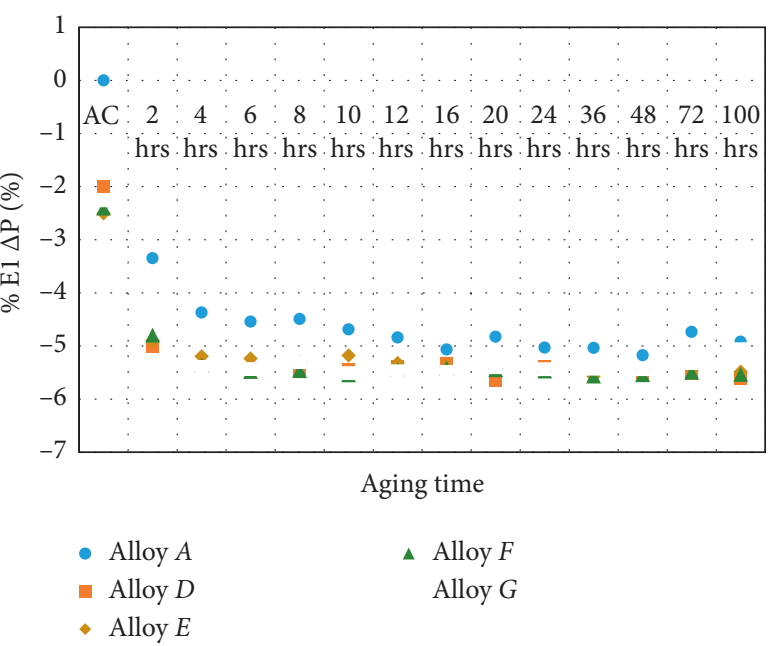

(c)

FIGURE 8: Comparison of tensile properties of $A, D, E, F, G$ alloys relative to those of $A$ alloy in the as-cast condition: (a) UTS, (b) YS, and (c) $\% \mathrm{El}$ at $170^{\circ} \mathrm{C}$. Same legends as in Figure $8(\mathrm{a})$.

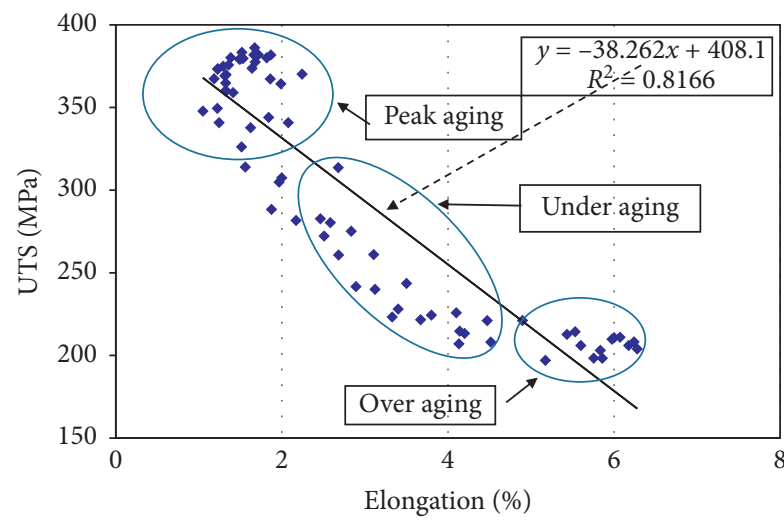

(a)

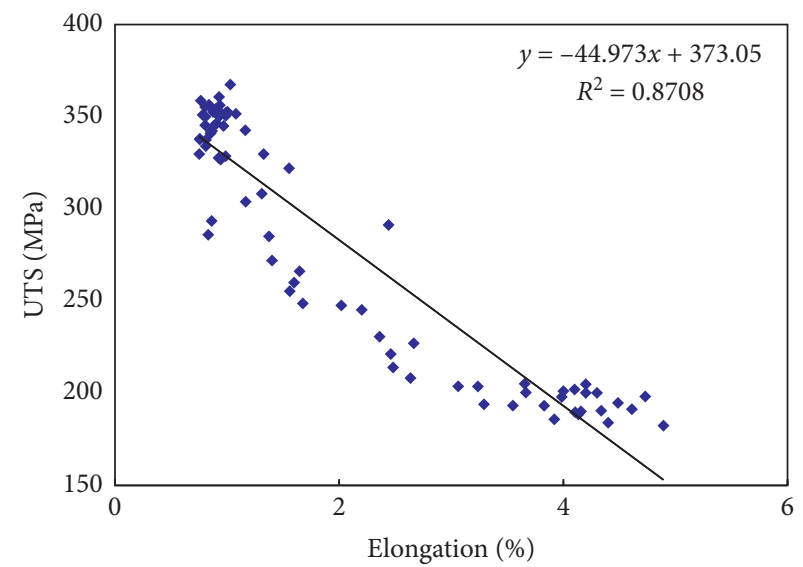

(b)

FIgURE 9: The UTS vs. \% El relationship for (a) alloy $A$ and (b) alloy $F$. 

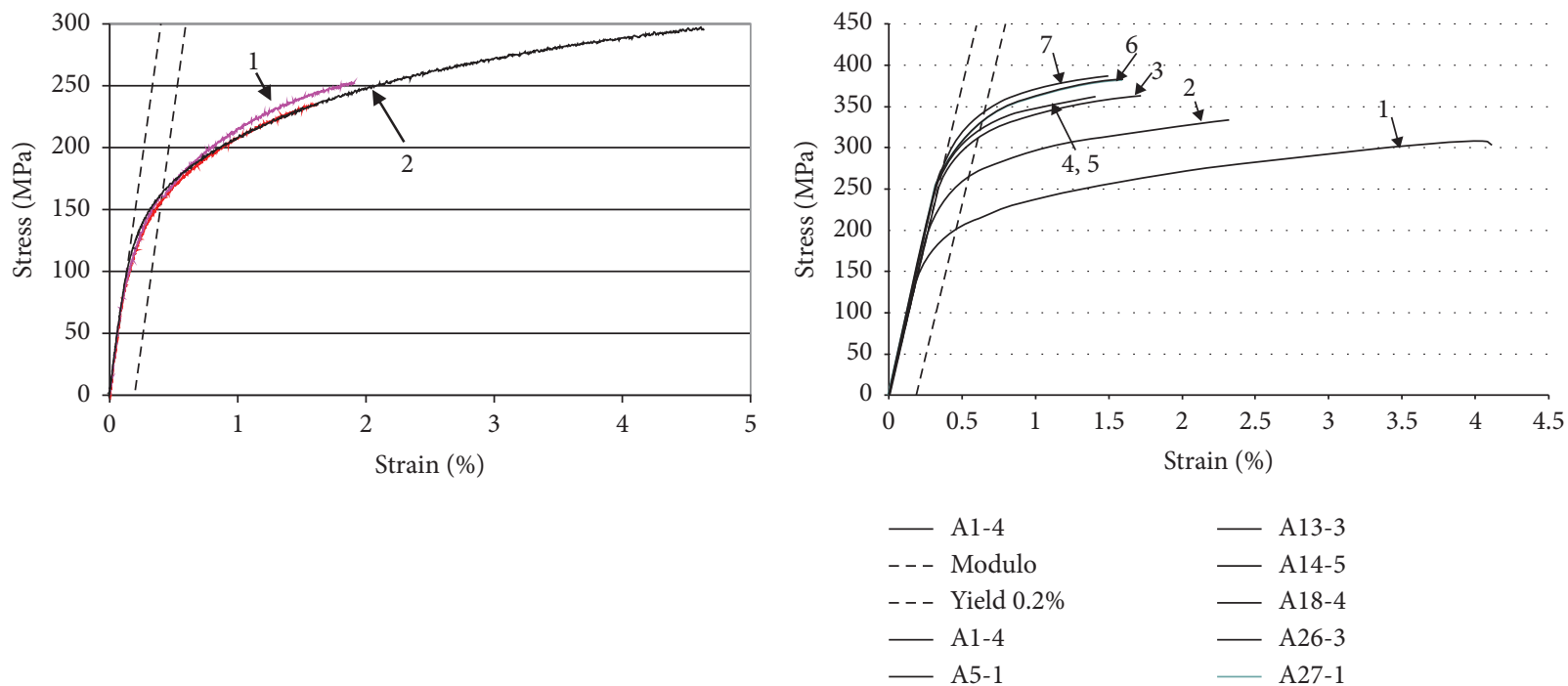

(a)

(b)

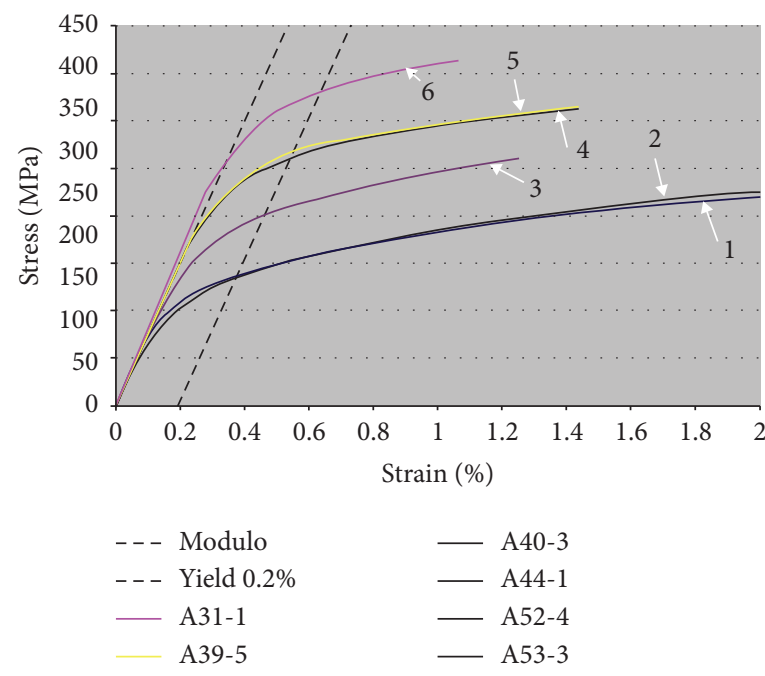

(c)

FIgURE 10: A series of stress-strain diagrams used to calculate the $\mathrm{n}$ and $\mathrm{K}$ values (see Table 6 for details).

TABLe 6: Aging condition for curves shown in Figure 10(a)-10(c).

\begin{tabular}{lcc}
\hline Figure \# & Curve \# & Aging condition \\
\hline \multirow{2}{*}{10 (a) } & 1 & As cast \\
& 2 & SHT \\
\hline & 1 & $2 \mathrm{~h} / 155^{\circ} \mathrm{C}$ \\
& 2 & $2 \mathrm{~h} / 170^{\circ} \mathrm{C}$ \\
& 3 & $10 \mathrm{~h} / 155^{\circ} \mathrm{C}$ \\
$10(\mathrm{~b})$ & 4 & $100 \mathrm{~h} / 155^{\circ} \mathrm{C}$ \\
& 5 & $2 \mathrm{~h} / 190^{\circ} \mathrm{C}$ \\
& 6 & $12 \mathrm{~h} / 170^{\circ} \mathrm{C}$ \\
& 7 & $100 \mathrm{~h} / 155^{\circ} \mathrm{C}$ \\
\hline & 1 & $2 \mathrm{~h} / 350^{\circ} \mathrm{C}$ \\
& 2 & $100 \mathrm{~h} / 240^{\circ} \mathrm{C}$ \\
$10(\mathrm{c})$ & 3 & $10 \mathrm{~h} / 240^{\circ} \mathrm{C}$ \\
& 4 & $2 \mathrm{~h} / 240^{\circ} \mathrm{C}$ \\
& 5 & $100 \mathrm{~h} / 190^{\circ} \mathrm{C}$ \\
& 6 & $10 \mathrm{~h} / 190^{\circ} \mathrm{C}$ \\
\hline
\end{tabular}

was obtained with a maximum UTS value of about $387 \mathrm{MPa}$ after $100 \mathrm{~h}$. Apparently, alloy ductility plays a major role in determining the $Q$ level.

The $Q$ charts following aging at $170^{\circ} \mathrm{C}$ and $190^{\circ} \mathrm{C}$ are shown in Figures 11(c) and 11(d), respectively. Apparently, there is more than one C-curve due to multiple reactions that took place during the aging process. From Figure 11(c), the values of $Q$ decreased from $421 \mathrm{MPa}(2 \mathrm{~h})$ to a value of about $375 \mathrm{MPa}(100 \mathrm{~h})$. The stress-strain curve corresponding to minimum $Q$ value is displayed in Figure 10(b)curve \#6. With aging at the $190^{\circ} \mathrm{C} / 2 \mathrm{hr}$ condition, GP zones and $\theta^{\prime}$ precipitates develop such that they are coherent with the matrix; YS is thus increased because of the strain fields associated with these precipitates, which are sheared by the dislocations and subsequently lead to a low strain-hardening rate as shown in Figure 10(b)-curve \#5. 


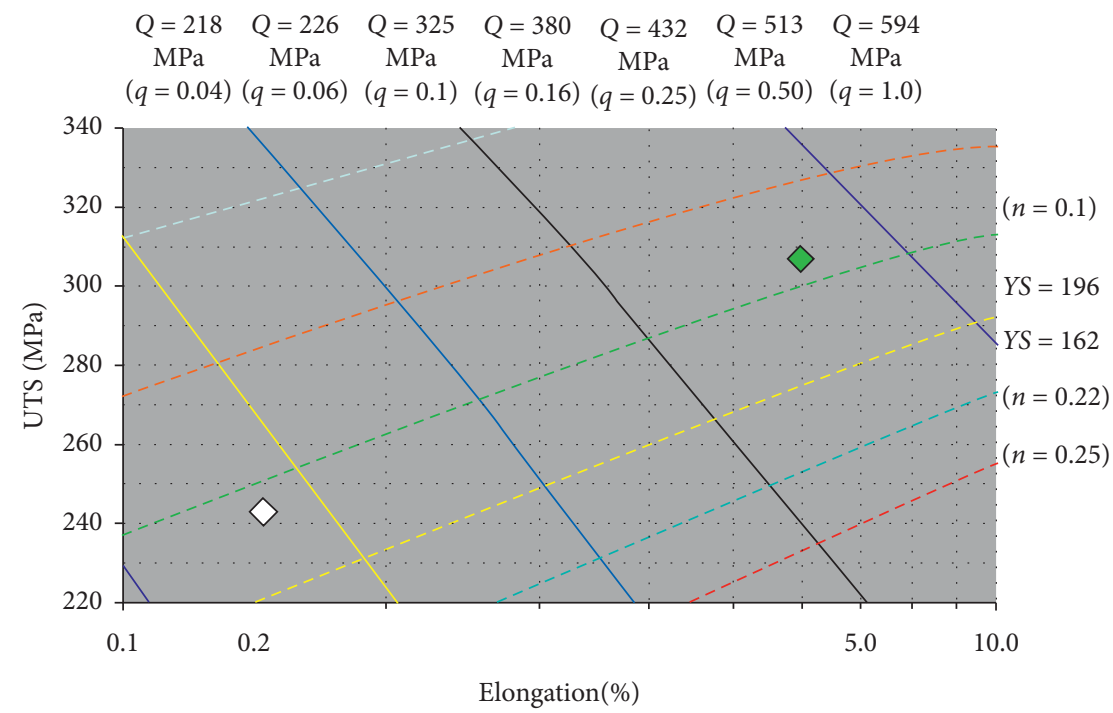

\section{$\diamond$ As-Cast-3A \\ HTSS-3A}

(a)

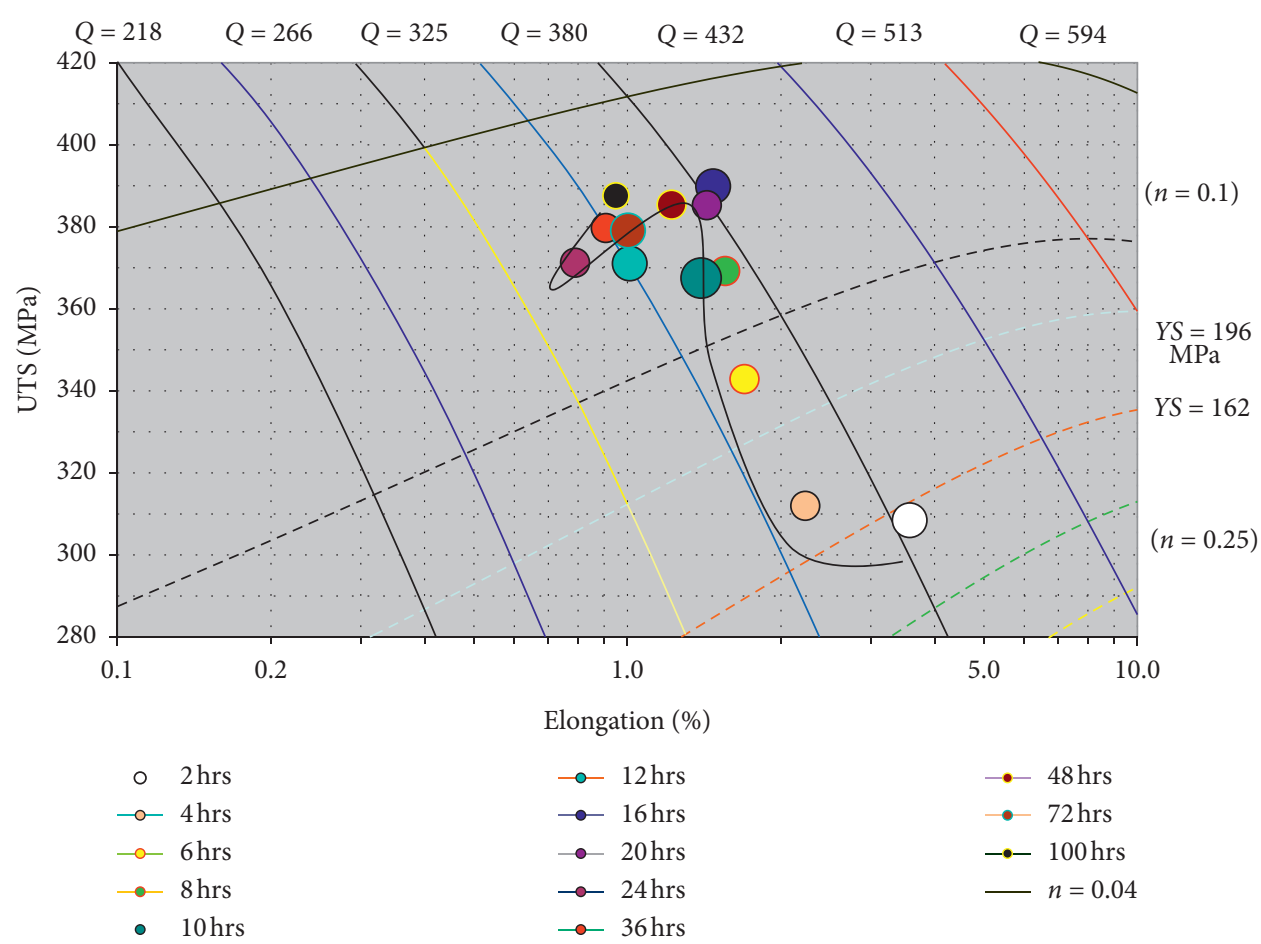

(b)

Figure 11: Continued. 


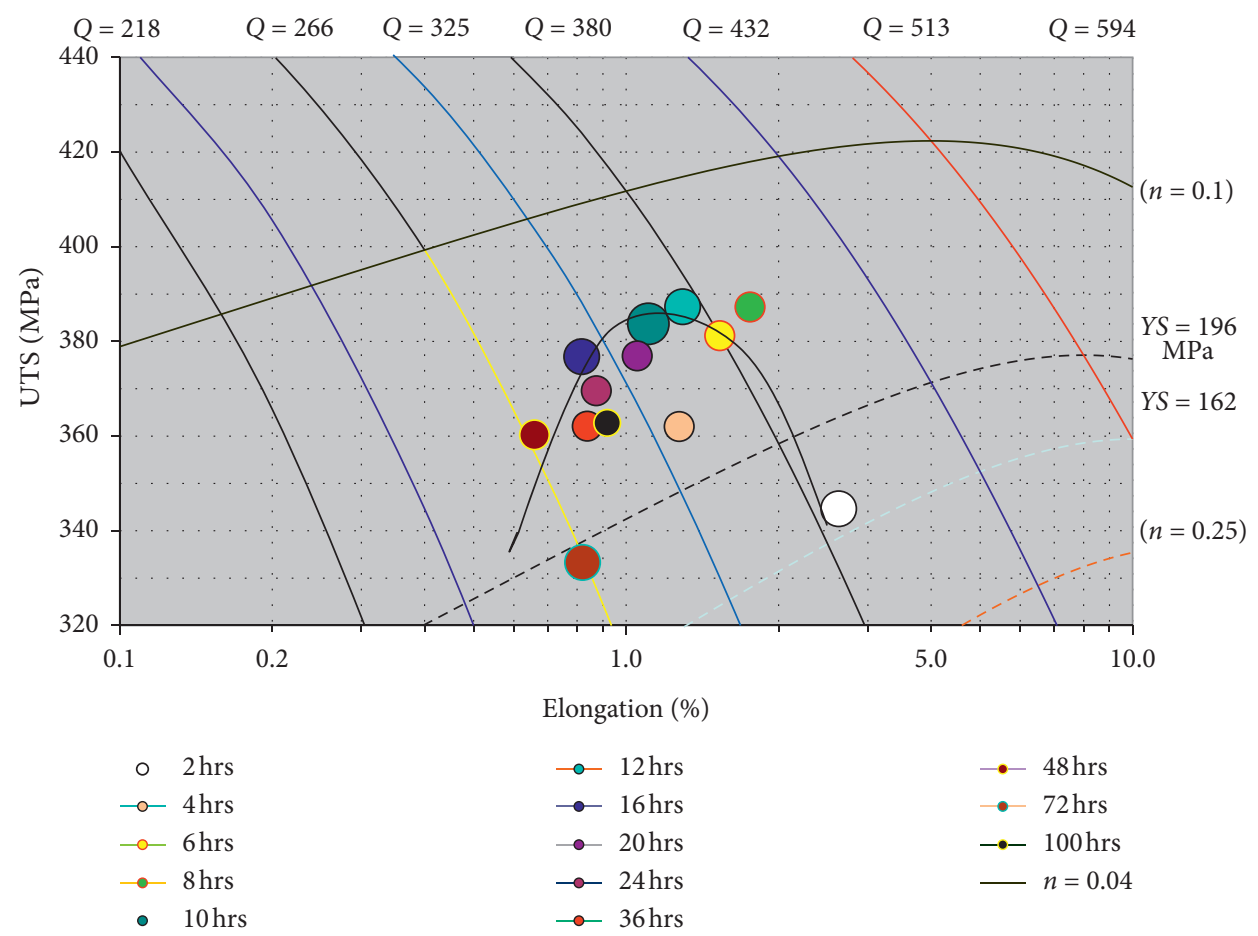

(c)

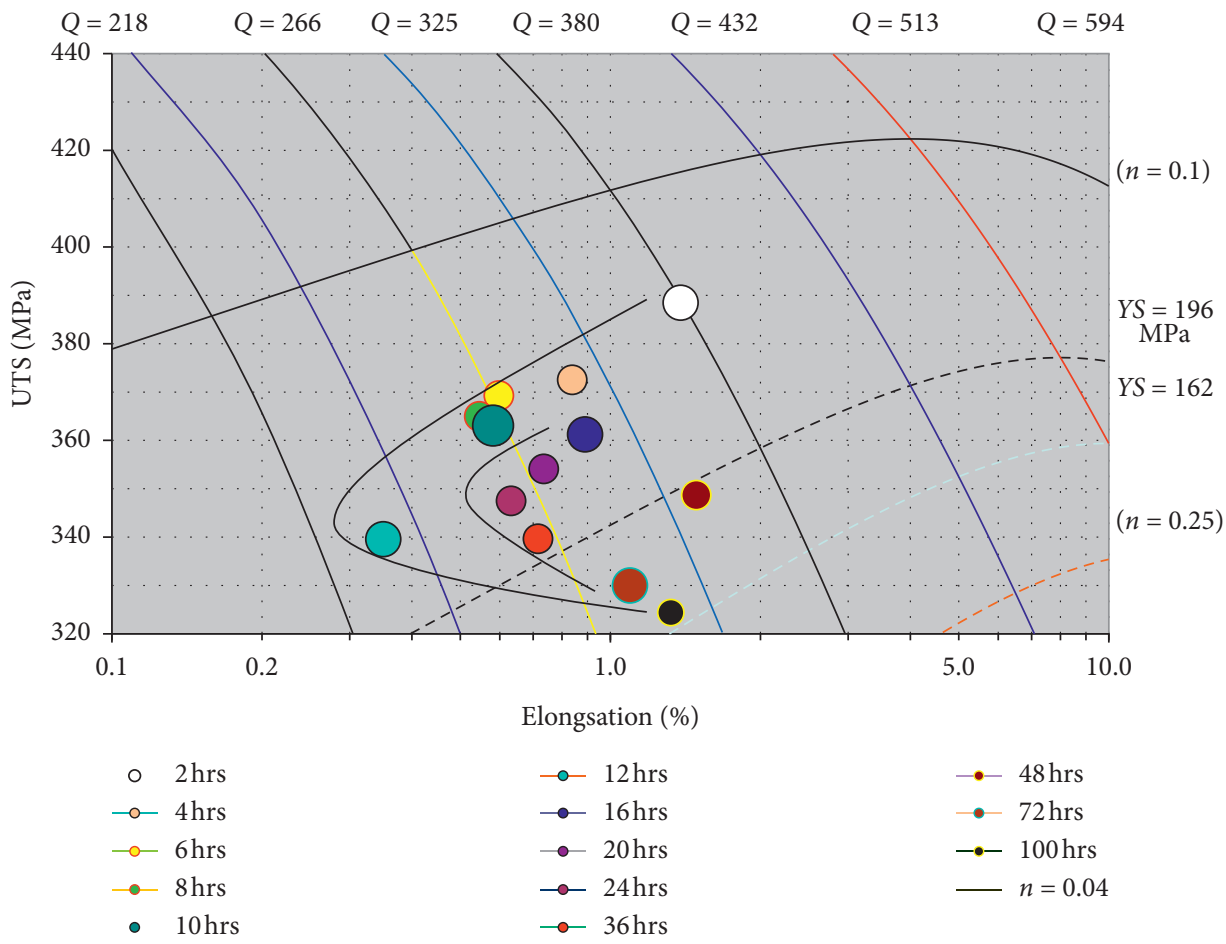

(d)

Figure 11: Continued. 


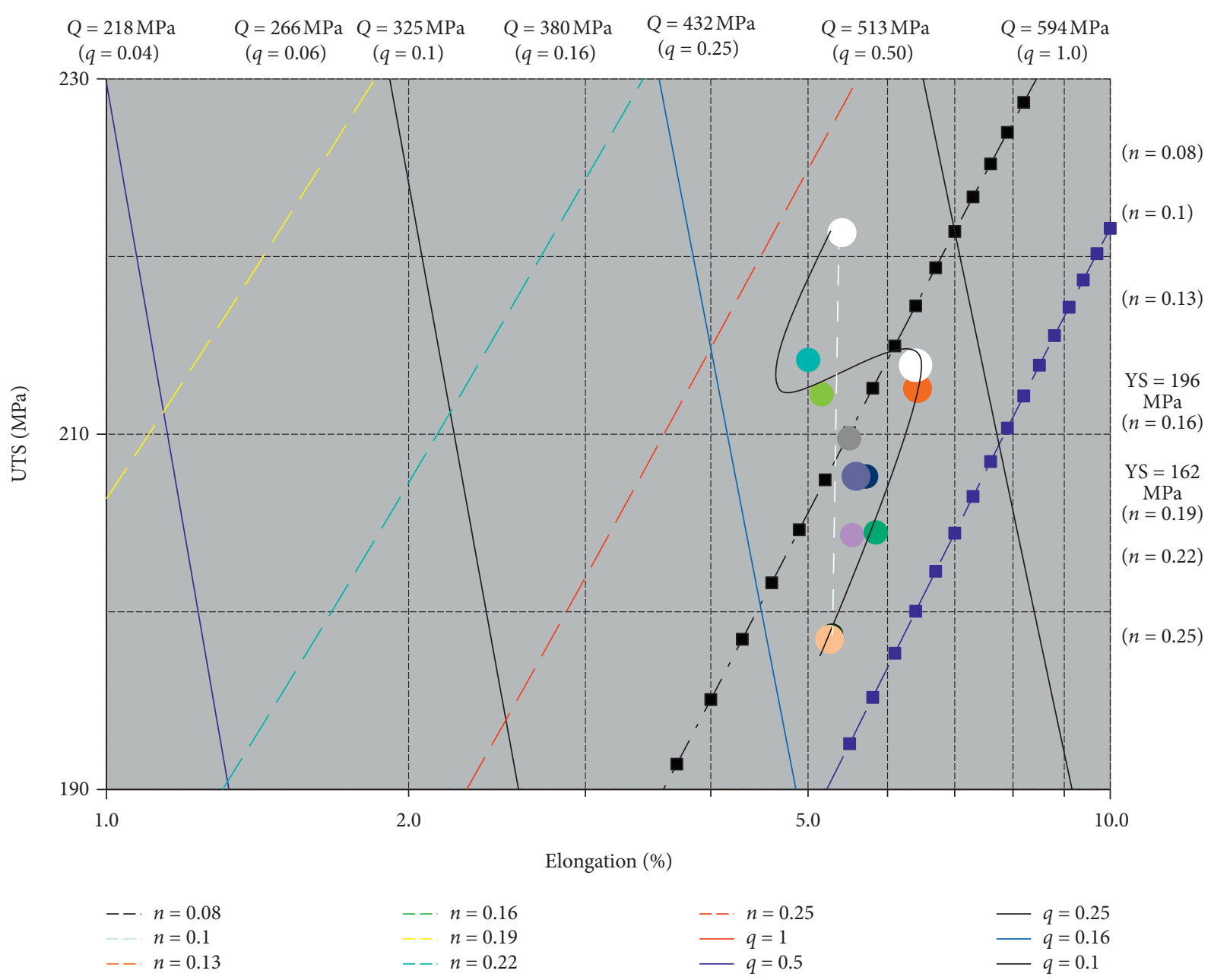

(e)

FIGURE 11: Quality index charts of alloy $A$ at different aging temperatures: (a) as-cast and SHT, (b) $155^{\circ} \mathrm{C}$, (c) $170^{\circ} \mathrm{C}$, (d) $190^{\circ} \mathrm{C}$, and (e) $350^{\circ} \mathrm{C}$.

Aging at $350^{\circ} \mathrm{C}$ resulted in a significant improvement in the alloy ductility. The chart in Figure 11(e) could be divided into two curves (solid line) or simple straight line $2 \mathrm{~h}-100 \mathrm{~h}$ (broken line). During the course of aging, the values of UTS level were reduced from $221 \mathrm{MPa}(2 \mathrm{~h})$ to $200 \mathrm{MPa}(100 \mathrm{~h})$ with significant increase in \% elongation from about $4.5 \%$ $(2 \mathrm{~h})$ (curve \#1 in Figure 10(c)) to 6.5\% (100 h) resulting in $Q$ values of $350-\mathrm{MPa}(2 \mathrm{~h})-345 \mathrm{MPa}(100 \mathrm{~h})$. In other words, practically there is no change in the $Q$ levels for the entire aging time $( \pm 5 \mathrm{MPa})$.

It may be deduced from Figure 4 that the $\theta-\mathrm{CuAl}_{2}$ precipitates are formed at temperatures of $190^{\circ} \mathrm{C}$ and higher, i.e., $350^{\circ} \mathrm{C}$ [53-55]. These particles are incoherent with the matrix and cannot be cut by dislocations, thereby promoting lower strength values and a high strain-hardening rate resulting from the accumulation of Orowan loops around the copper phase particles. As the strain is increased, however, the gradual development of primary shear loops generates intense stress fields around the strengthening precipitates, which are in themselves limited $[45,56,57]$ by the activation of a secondary dislocation cross-slip process, thus reducing the strain-hardening ability of the material.

\section{Conclusions}

From an analysis of the results obtained, the following conclusions may be formulated:

(1) Zirconium reacts only with $\mathrm{Ni}, \mathrm{Ti}, \mathrm{Si}$, and $\mathrm{Al}$ in the alloys which are examined to form two phases: $(\mathrm{Al}, \mathrm{Si})_{3}(\mathrm{Zr}, \mathrm{Ni}, \mathrm{Fe})$ and $(\mathrm{Al}, \mathrm{Si})_{3}(\mathrm{Zr}, \mathrm{Ti})$.

(2) There is no negative effect in the refinement of grain size with the addition of $\mathrm{Zr}$ to the alloys containing Ti. Addition of $0.2 \% \mathrm{Zr}$ resulted in about $40 \%$ reduction in the alloy grain size.

(3) Addition of $\mathrm{Zr}$ or $\mathrm{Zr}+\mathrm{Ni}$ has a minor effect on the alloy strength at aging temperatures as high as $240^{\circ} \mathrm{C}-350^{\circ} \mathrm{C}$ (over aging).

(4) For aging at $350 \mathrm{o} \mathrm{C}$ for times up to $100 \mathrm{~h}$, the YS values for alloy $G$ (with $0.2 \mathrm{wt} . \% \mathrm{Zr}$ and $0.2 \mathrm{wt} . \% \mathrm{Ni}$ ) increased by about $15 \%$ with respect to the rest of the alloys studied.

(5) Addition of $\mathrm{Zr}$ beyond $0.2 \%$, i.e., $0.4 \%$ is not recommended due to the high liquidus temperature $\left(\sim 780^{\circ} \mathrm{C}\right)$ of the $\mathrm{Al}-\mathrm{Zr}$ binary phase diagram. 
(6) Nickel reacts with $\mathrm{Cu}$ resulting in a decrease in the alloy tensile properties by about $10 \%(\sim 30 \mathrm{MPa})$.

(7) Quality index charts could represent more than a single precipitation reaction, as inferred from the presence of multiple $\mathrm{C}$ curves. In such category of alloys, ductility plays a decisive role in determining the $Q$ levels.

\section{Data Availability}

The data used to support the findings of this study are available from the corresponding author upon request.

\section{Conflicts of Interest}

The authors declare that they have no conflicts of interest.

\section{Acknowledgments}

The authors would like to acknowledge the use of a part of the $\mathrm{PhD}$ thesis of Dr. J. Hernandez-Sandoval (first author) in the present article.

\section{Supplementary Materials}

Figure A1. Comparison of tensile properties of $A, D, E, F, G$ alloys relative to those of $A$ alloy in the as-cast condition: (a) UTS, (b) YS, and (c) $\% \mathrm{El}$ at $155^{\circ} \mathrm{C}$. Same legends as in (a). Figure A2. Comparison of tensile properties of $A, D, E, F, G$ alloys relative to those of $A$ alloy in the as-cast condition: (a) UTS, (b) YS, and (c) $\% \mathrm{El}$ at $350^{\circ} \mathrm{C}$. Same legends as in (a). (Supplementary Materials)

\section{References}

[1] D. G. Eskin, "Decomposition of supersaturated solid solutions in Al-Cu-Mg-Si alloys," Journal of Materials Science, vol. 38, no. 2, pp. 279-290, 2003.

[2] S. K. Son, M. Takeda, M. Mitome, Y. Bando, and T. Endo, "Precipitation behavior of an Al-Cu alloy during isothermal aging at low temperatures," Materials Letters, vol. 59, no. 6, pp. 629-632, 2005.

[3] S. P. Ringer and K. Hono, "Microstructural evolution and age hardening in aluminium alloys," Materials Characterization, vol. 44, no. 1-2, pp. 101-131, 2000.

[4] C. R. Hutchinson and S. P. Ringer, "Precipitation processes in $\mathrm{Al}-\mathrm{Cu}-\mathrm{Mg}$ alloys microalloyed with Si," Metallurgical and Materials Transactions A, vol. 31, no. 11, pp. 2721-2733, 2000.

[5] S. Abis, M. Massazza, P. Mengucci, and G. Riontino, "Early ageing mechanisms in a high-copper AlCuMg alloy," Scripta Materialia, vol. 45, no. 6, pp. 685-691, 2001.

[6] G. E. Totten and D. S. Mackenzie, Handbook of Aluminum, Vol. 1: Physical Metallurgy and Processes, Marcel Dekker, New York, NY, U.S.A., 2003.

[7] S. C. Wang, M. J. Starink, and N. Gao, "Precipitation hardening in $\mathrm{Al}-\mathrm{Cu}-\mathrm{Mg}$ alloys revisited," Scripta Materialia, vol. 54, no. 2, pp. 287-291, 2006.

[8] P. Ratchev, B. Verlinden, P. De Smet, and P. Van Houtte, "Effect of cooling rate and predeformation on the precipitation hardening of an Al-4.2wt $\% \mathrm{Mg}-0.6 \mathrm{wt} \% \mathrm{Cu}$ alloy," Scripta Materialia, vol. 38, no. 8, pp. 1195-1201, 1998.
[9] T. W. Charai and C. Y. Zabra, "Coexistence of clusters, GPB zones, S"-, S' - and S-phases in an Al-0.9\% Cu-1.7\%Mg alloy," Acta Materialia, vol. 48, pp. 2751-2764, 2000.

[10] P. Ratchev, B. Verlinden, P. De Smet, and P. Van Houtte, "Precipitation hardening of an Al-4.2wt\%Mg-0.6wt\%Cu alloy," Acta Materialia, vol. 46, no. 10, pp. 3523-3533, 1998.

[11] C. Cayron and P. A. Buffat, "Transmission electron microscopy study of the $\beta^{\prime}$ phase (Al-Mg-Si alloys) and QC phase (Al-Cu-Mg-Si alloys): ordering mechanism and crystallographic structure," Acta Materialia, vol. 48, no. 10, pp. 2639-2653, 2000.

[12] K. Matsuda, D. Teguri, T. Sato, and S. Ikeno, "EFTEM observation of Q' phase in Al-Mg-Si-Cu alloy," Materials Science Forum, vol. 396-402, pp. 947-952, 2002.

[13] J. Y. Hwang, R. Banerjee, H. W. Doty, and M. J. Kaufman, "The effect of $\mathrm{Mg}$ on the structure and properties of type 319 aluminum casting alloys," Acta Materialia, vol. 57, no. 4, pp. 1308-1317, 2009.

[14] G. Wang, Q. Sun, L. Feng, L. Hui, and C. Jing, "Influence of $\mathrm{Cu}$ content on ageing behavior of AlSiMgCu cast alloys," Materials \& Design, vol. 28, no. 3, pp. 1001-1005, 2007.

[15] J. Buha, R. N. Lumley, and A. G. Crosky, "Microstructural development and mechanical properties of interrupted aged Al-Mg-Si-Cu alloy," Metallurgical and Materials Transactions A, vol. 37, no. 10, pp. 3119-3130, 2006.

[16] G. A. Edwards, K. Stiller, G. L. Dunlop, and M. J. Couper, "The precipitation sequence in Al-Mg-Si alloys," Acta Materialia, vol. 46, pp. 3893-3904, 1998.

[17] H. R. Ammar, A. M. Samuel, F. H. Samuel, E. Simielli, G. K. Sigworth, and J. C. Lin, "Influence of aging parameters on the tensile properties and quality index of Al-9 pct Si-1.8 pct Cu-0.5 pct Mg 354-type casting alloys," Metallurgical and Materials Transactions A, vol. 43A, pp. 61-73, 2012.

[18] J. Hernandez-Sandoval, "Improving the performance of 354 type alloy,” $\mathrm{PhD}$. Thesis, Université du Québec à Chicoutimi, Chicoutimi, Canada, 2010.

[19] J. Hernandez-Sandoval, G. H. Garza-Elizondo, A. M. Samuel, S. Valtiierra, and F. H. Samuel, "The ambient and high temperature deformation behavior of $\mathrm{Al}-\mathrm{Si}-\mathrm{Cu}-\mathrm{Mg}$ alloy with minor Ti, Zr, Ni additions," Materials \& Design, vol. 58, pp. 89-101, 2014.

[20] D. Apelian, "Aluminum Cast Alloys: Enabling Tools for Improved Performance," Worldwide Report, NADCA, Arlington Heights, IL, USA, 2009.

[21] Q. G. Wang, "Microstructural effects on the tensile and fracture behavior of aluminum casting alloys A354/357," Metallurgical and Materials Transactions A, vol. 34, no. 12, pp. 2887-2899, 2003.

[22] K. I. Moon, K. Y. Chang, and K. S. Lee, "The effect of ternary addition on the formation and the thermal stability of L12 $\mathrm{Al} 3 \mathrm{Zr}$ alloy with nanocrystalline structure by mechanical alloying," Journal of Alloys and Compounds, vol. 312, no. 1-2, pp. 273-283, 2000.

[23] K. E. Knipling, "Development of a nanoscale precipitationstrengthened creepresistant aluminum alloy containing trialuminide precipitates," $\mathrm{PhD}$ Thesis, Northwestern University, Evanston, IL, USA, 2006.

[24] W. L. Manknis and S. Lamb, "Nickel and nickel alloys," Metals Handbook, vol. Vol. 2pp. 1374-1380, Materials Park, OH, USA, 10 edition, 1990.

[25] Z. Asghar, G. Requena, and F. Kubel, "The role of Ni and Fe aluminides on the elevated temperature strength of an AlSi12 alloy," Materials Science and Engineering: A, vol. 527, no. 2122, pp. 5691-5698, 2010. 
[26] M. S. Jo, Y. H. Cho, J. M. Lee et al., “A new Zr-rich intermetallic phase in an Al-14Si-3Cu-4.5Ni casting alloy with trace additions of Zr," Intermetallics, vol. 117, Article ID 106667, 2020.

[27] R. A. Michi, J. P. Toinin, D. N. Seidman, and D. C. Dunand, "Ambient- and elevated-temperature strengthening by Al3ZrNanoprecipitates and Al3Ni-Microfibers in a cast Al-2.9Ni0.11Zr-0.02Si-0.005Er (at. \%) alloy," Materials Science and Engineering: A, vol. 759, pp. 78-89, 2019.

[28] T. Tunçay, D. Özyürek, D. Dişpinar, and S. Tekeli, “The effects of $\mathrm{Cr}$ and $\mathrm{Zr}$ additives on the microstructure and mechanical properties of A356 alloy," Transactions of the Indian Institute of Metals, vol. 73, no. 5, pp. 1273-1285, 2020.

[29] M. Drouzy, S. Jacob, and M. Richard, "Interpretation of tensile results by means of quality index and probable yield strength," AFS International Cast Metals Journal, vol. 5, pp. 43-50, 1980.

[30] C. H. Cáceres, T. Din, A. K. M. B. Rashid, and J. Campbell, "Effect of aging on quality index of an Al-Cu casting alloy," Materials Science and Technology, vol. 15, no. 6, pp. 711-716, 1999.

[31] L. Ceschini, I. Boromei, A. Morri, S. Seifeddine, and I. L. Svensson, "Microstructure, tensile and fatigue properties of the $\mathrm{Al}-10 \% \mathrm{Si}-2 \% \mathrm{Cu}$ alloy with different $\mathrm{Fe}$ and $\mathrm{Mn}$ content cast under controlled conditions," Journal of Materials Processing Technology, vol. 209, pp. 5669-5679, 2009.

[32] C. H. Cáceres, Microstructure Design and Heat Treatment Selection for Casting Alloys Using the Quality Index, ASM, Cincinnati, OH, USA, 1999.

[33] D. Srinivasan and K. Chattopadahyay, "Metastable phase evolution and hardness of nanocrystalline Al-Si-Zr alloys," Materials Science and Engineering A, vol. 304-306, pp. 534539, 2018.

[34] F. H. Samuel, "Incipient melting of Al5Mg8Si6Cu2 and $\mathrm{Al} 2 \mathrm{Cu}$ intermetallics in unmodified and strontium-modified Al-Si$\mathrm{Cu}-\mathrm{Mg}$ (319) alloys during solution heat treatment," Journal of Materials Science, vol. 33, no. 9, pp. 2283-2297, 1998.

[35] P. Sepehrband, R. Mahmudi, and F. Khomamizadeh, "Effect of $\mathrm{Zr}$ addition on the aging behavior of A319 aluminum cast alloy," Scripta Materialia, vol. 52, no. 4, pp. 253-257, 2005.

[36] R. Mahmudi, P. Sepehrband, and H. M. Ghasemi, "Improved properties of A319 aluminum casting alloy modified with Zr," Materials Letters, vol. 60, no. 21-22, pp. 2606-2610, 2006.

[37] W. Chen, Y. Wang, J. Qiang, and C. Dong, "Bulk metallic glasses in the Zr-Al-Ni-Cu system," Acta Materialia, vol. 51, no. 7, pp. 1899-1907, 2003.

[38] M. H. Abdelaziz, H. W. Doty, S. Valtierra, and F. H. Samuel, "Static versus dynamic thermal exposure of transition elements-containing Al-Si-Cu-Mg cast alloy," Materials Science and Engineering: A, vol. 739, pp. 499-512, 2019.

[39] F. H. Samuel, A. M. Samuel, and H. W. Doty, "Factors controlling the type and morphology of $\mathrm{Cu}$-containing phases in 319 Al alloys," AFS Transactions, vol. 104, pp. 893-901, 1996.

[40] W. Kurz and D. J. Fisher, Fundamentals of Solidification, TransTech. Publications Ltd., Uetikon-Zuerich, Switzerland, 1998.

[41] J. Murray, A. Peruzzi, and J. P. Abriata, "The Al-Zr (aluminum-zirconium) system," Journal of Phase Equilibria, vol. 13, no. 3, pp. 277-291, 1992.

[42] S. K. Chaudhury and D. Apelian, "Fluidized bed heat treatment of cast Al-Si-Cu-Mg alloys," Metallurgical and Materials Transactions A, vol. 37, no. 7, pp. 2295-2311, 2006.

[43] H. R. Ammar, A. M. Samuel, and F. H. Samuel, "Porosity and the fatigue behavior of hypoeutectic and hypereutectic aluminum-silicon casting alloys," International Journal of Fatigue, vol. 30, no. Issue 6, pp. 1024-1035, June 2008.

[44] C. H. Cáceres and J. A. Taylor, "Enhanced ductility in Al-Si$\mathrm{Cu}-\mathrm{Mg}$ casting alloys with high Si content," in Shape Casting: The John Campbell Symposium, M. Tiryakiouglu and P. Crepeau, Eds., pp. 245-254, TMS, San Diego,CA, USA, 2005.

[45] E. Sjölander and S. Seifeddine, "The heat treatment of Al-Si$\mathrm{Cu}-\mathrm{Mg}$ casting alloys," Materials Processing Technology, vol. 210, no. 10, pp. 1249-4259, 2010.

[46] M. F. Ibrahim, M. H. Abdelaziz, H. W. Doty, S. Valtierra, and F. H. Samuel, "Effect of microalloying elements on the heat treatment response and tensile properties of Al-Si-Mg alloys," in Solidification, A. E. Ares, Ed., InTech, Rijeka, Croatia, 2018.

[47] F. J. Tavitas-Medrano, J. E. Gruzleski, F. H. Samuel, S. Valtierra, and H. W. Doty, "Conventional versus nonconventional aging heat treatments of 319-type alloys in relation to their mechanical properties," in Proceedings of the Symposium on Aluminium: From Raw Materials to Applications, 45th Annual Conf. Of Metallurgists of CIM, pp. 185-200, Montreal, Canada, 2006.

[48] A. I. Ibrahim, A. M. Samuel, F. H. Samuel, and H. W. Doty, "Response of varying levels of silicon and transition elements on room and elevated temperature tensile properties in an Al$\mathrm{Cu}$ alloy," in Proceedings of the 122nd Metalcasting Congress, American Foundry Society, Fort Worth, TX, USA, 2018.

[49] A. M. A Mohamed and F. H. Samuel, "A review on the heat treatment of Al-Si-Cu/Mg casting alloys," in Heat Treatment: Conventional and Novel Applications, F. Czerwinski, Ed., InTech Open, London, UK, 2012.

[50] A. M. Samuel, S. S. Mohamed, H. W. Doty, S. Valtierra, and F. H. Samuel, "Grain refining of Al-Si alloys using Al-10\% Ti master alloy: role of $\mathrm{Zr}$ addition," International Journal of Cast Metals Research, vol. 32, no. 1, pp. 46-58, 2019.

[51] L. Alyaldin, M. H. Abdelaziz, A. M. Samuel, H. W. Doty, S. Valtierra, and F. H. Samuel, "Effect of Ni and Mn additions on the ambient and high-temperature performance of $\mathrm{Zr}$ containing $\mathrm{Al}-\mathrm{Si}-\mathrm{Cu}-\mathrm{Mg}$-based alloys: role of precipitation hardening," International Journal of Metalcasting, vol. 12, no. 4, pp. 825-838, 2018.

[52] J. Hernandez-Sandoval, A. M. Samuel, S. Valtierra, and F. H. Samuel, "Thermal analysis for detection of Zr-rich phases in $\mathrm{Al}-\mathrm{Si}-\mathrm{Cu}-\mathrm{Mg}$ 354-type Alloys," International Journal of Metalcasting, vol. 11, no. 3, pp. 428-439, 2017.

[53] M. Huang and Z. Li, "Size effects on stress concentration induced by a prolate ellipsoidal particle and void nucleation mechanism," International Journal of Plasticity, vol. 21, pp. 1568-1590, 2005.

[54] B. J. Lee and M. E. Mear, "Stress concentration induced by an elastic spheroidal particle in a plastically deforming solid," Journal of the Mechanics and Physics of Solids, vol. 47, pp. 1301-1336, 1999.

[55] M. H. Abdelaziz, A. M. Samuel, F. H. Samuel, and H. W. Doty, "Various aspects influencing the fracture behavior of impacttested $\mathrm{Zr}$-containing $\mathrm{Al}-\mathrm{Si}-\mathrm{Cu}-\mathrm{Mg}$-354-type alloys," International Journal of Metalcasting, 2021.

[56] F. Fracasso, "Influence of quench rate on the hardness obtained after artificial ageing of an Al-Si-Mg alloy," Master Thesis, University of Padova, Padova, Italy, 2010.

[57] E. Sjölander and S. Seifeddine, "Artificial ageing of $\mathrm{Al}-\mathrm{Si}-\mathrm{Cu}-\mathrm{Mg}$ casting alloys," Materials Science and Engineering: $A$, vol. 528, no. 24, pp. 7402-7409, 2011. 